\title{
Sampling and Characterization of Sodium-Water Reaction Products
}

By

\section{R.L. Eichelberger}

$$
\begin{aligned}
& \text { This report was prepared as an account of work } \\
& \text { sponsored by the United States Government. Neither the } \\
& \text { United States nor the United States Department of } \\
& \text { Energy, nor any of their employees, nor any of their } \\
& \text { contractors, subcontractors, or their employees, makes } \\
& \text { any warranty, express or implied, or assumes any legal } \\
& \text { liability or responsibility for the accuracy, completeness } \\
& \text { or usefulness of any information, apparatus, product or } \\
& \text { process disclosed, or represents that its use would not } \\
& \text { infringe privately owned rights. }
\end{aligned}
$$

This document is
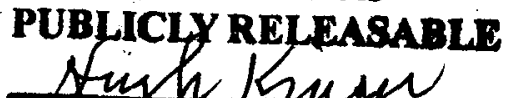

Antiniting Oindt

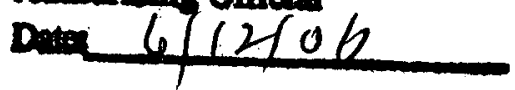

\section{Liquid Metal Engineering Center}

Operated for

the U.S. Department of Energy by Atomics International Division

Rockwell International Corporation

Contract: EY-76-C-03-0700

Issued: December 15, 1977

Released For Announcement in Enersy

Research Abstracts. Distribution Limited to Partieipants in trie-LMFBR Program. thers request from TIC 


\section{DISCLAIMER}

This report was prepared as an account of work sponsored by an agency of the United States Government. Neither the United States Government nor any agency Thereof, nor any of their employees, makes any warranty, express or implied, or assumes any legal liability or responsibility for the accuracy, completeness, or usefulness of any information, apparatus, product, or process disclosed, or represents that its use would not infringe privately owned rights. Reference herein to any specific commercial product, process, or service by trade name, trademark, manufacturer, or otherwise does not necessarily constitute or imply its endorsement, recommendation, or favoring by the United States Government or any agency thereof. The views and opinions of authors expressed herein do not necessarily state or reflect those of the United States Government or any agency thereof. 


\section{DISCLAIMER}

Portions of this document may be illegible in electronic image products. Images are produced from the best available original document. 


\section{DISTRIBUTION}

Liquid Metal Engineering Center - Internal:

Director, LMEC PO (DOE)

R. L. Eichelberger

R. E. Fenton

R. K. Wagner

(18) LMEC Library

External:

Chief, DOE California Patent Group, SAN

Patent Counsel, AI

Information Services, AI

(215) DOE Technical Information Center for distribution under TID-4500-R66, Category UC-79k

\section{ACKNOWLEDGMENT}

The sampling tool was designed by R. S. Kennedy. Analytical chemistry was carried out by W. A. MCollum, M. S. Maseda, R. B. Litsinger, C. H. Trippeda, and R. C. Shepard of the LMEC Chemistry and Metallurgical Laboratory, managed by D. E. Goggin. The contributions of these individuals to this report are gratefully a cknowledged. 


\section{CONTENTS}

Page

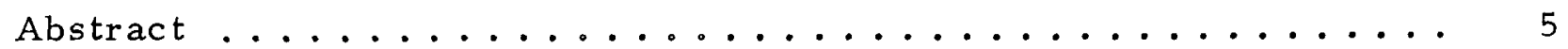

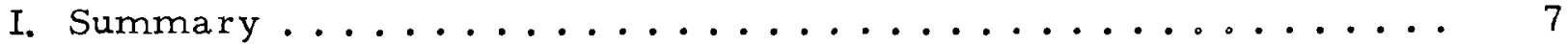

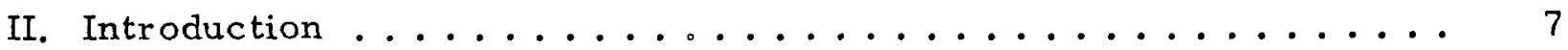

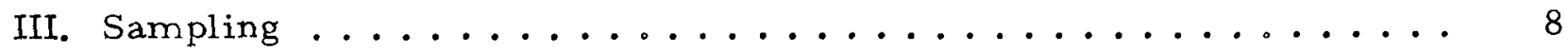

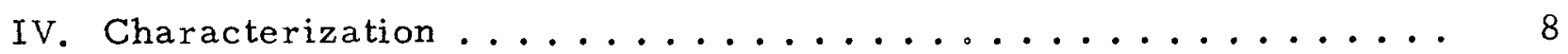

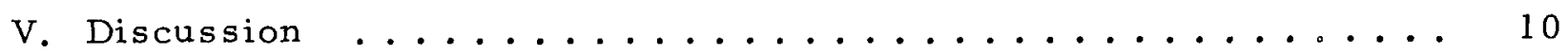

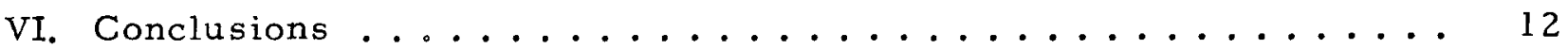

Appendixes

A. Procedure for Sampling Sodium-Water Reaction Products

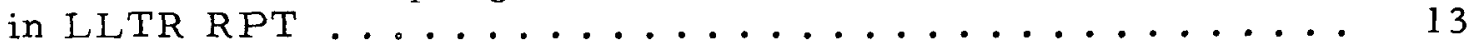

B. Characterization of SWRP Sample, Procedure, and Results . . 19

FIGURES

1. Sample Collector Assembly ......................... 9

B1. Head Section of SWRP Sampler (in glove box) . . . . . . . . . . 34

B2. Top View Into Sampler . . . . . . . . . . . . . . . . 34

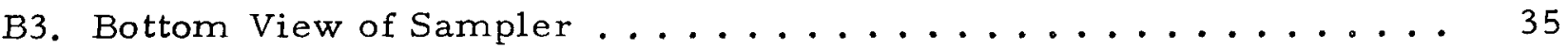

B4. SWRP Sample After Removal From Sampler (side view) . . . . . 35

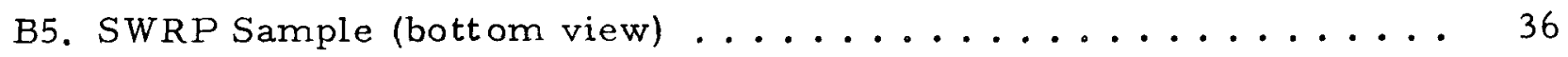

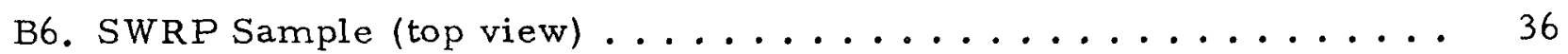

B7. SWRP Sample Sectioned Into Five Parts ............ 37

B8. Cross-Section of SWRP Near Bottom, Showing Inclusions . . . . . 37

B9. SWRP Sample Mounted in X-ray Diffraction Sample Holder . . . . . 38

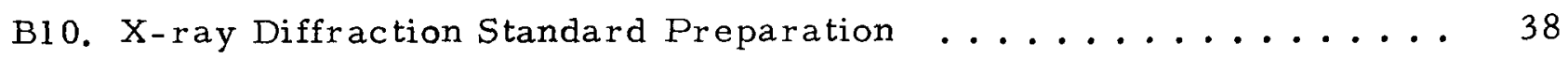

B11. Sections of SWRP, Showing Where Amalgamation Samples

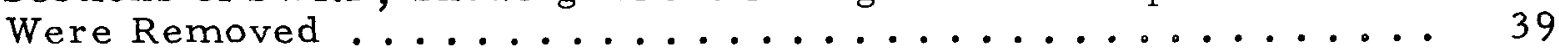

B12. Amalgamation Analysis, Showing Oxide Residue Floating

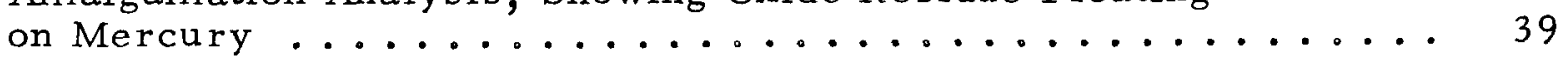

Bl3. Close-Up View of Oxide Residue on Mercury . . . . . . . . . 40

B14. Samples (center) Taken From SWRP Sections for Hydrogen Analysis ....................... 40

B15. SWR P Sample From Section No. I in Tantalum Crucible

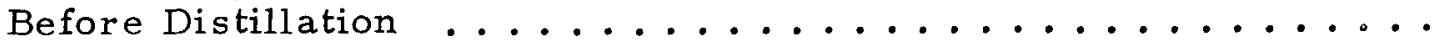




\section{FIGURES}

Page

B16. SWRP Sample From Section No. 4 in Tantalum Crucible

Before Distillation ..................... 41

B17. Distillation Residue From Section No. $1 \ldots \ldots 42$

B18. Distillation Residue From Section No. $4 \ldots \ldots . \ldots . \ldots$

B19. Distillation Residue From SWRP Section No. 1: Separated

Chunks in Mortar, Residue After Grinding in Crucible . . . . . . 44

B20. Chunks Removed From SWRP Section No. 4 Distillation

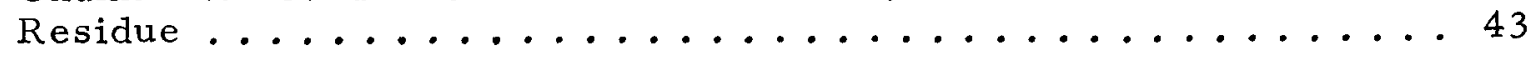

B21. SWRP Section No. 4 Distillation Residue After Grinding to

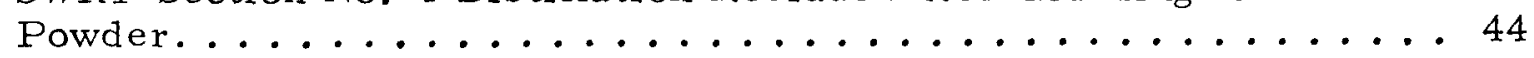

B22. Scanning Electron Micrograph of Magnetic Particles Recovered

From SWRP Solution in Ethanol, 200X ............. 44

B23. Scanning Electron Micrograph of Magnetic Particles

Recovered From SWRP Solution in Dowanol PM, 200X ....... 45

B24. SWRP Sample ( $15.3 \mathrm{~g})$ in Glove Box at $550^{\circ} \mathrm{F} \ldots \ldots . \ldots 45$

B25. Close-Up View of SWRP Sample at $500^{\circ} \mathrm{F} \ldots \ldots . \ldots$

B26. SWRP Sample $(28.4 \mathrm{~g})$ in Tantalum Cup After

Heating to $800^{\circ} \mathrm{F} \ldots \ldots \ldots \ldots \ldots$ 


\begin{abstract}
The products of sodium-water reactions which had taken place in the Large Leak Test Rig at the Liquid Metal Engineering Center were sampled and characterized. The products consisted of the expected compounds in the $\mathrm{Na}-\mathrm{O}-\mathrm{H}$ system, and dissolved readily in ethanol. Removal of such products from a system by melting and draining does not appear feasible, but removal by dissolution in alcoholic solvents should be investigated further.
\end{abstract}




\section{SUMMARY}

Sodium-water reaction products (SWRP) which had accumulated in the bottom of the reaction products tank (RPT) of the Large Leak Test Rig (LLTR) were sampled and characterized. Analysis showed that the SWRP consisted of $\mathrm{NaOH}, \mathrm{Na}_{2} \mathrm{O}, \mathrm{NaH}$, and $\mathrm{Na}$, as expected, in varying proportions. The unreacted sodium in the samples examined ranged from 32 to $60 \%$ by weight.

The SWRP reacts (dissolves) rapidly and completely with ethanol, and somewhat less rapidly and completely with Dowanol PM. A magnetic, metallic residue was left, originating in the Croloy - 2-1/4 of the test article in the LLTR. These solvents should be investigated further as possible agents for cleaning sodium systems that are highly contaminated with water reaction products.

The SWRP does not completely liquefy with heating to $800^{\circ} \mathrm{F}\left(427^{\circ} \mathrm{C}\right)$. Although it softens to a consistency similar to that of wet sand, it is unlikely that it would flow or could be pumped even at such elevated temperature. The presence of highly corrosive molten $\mathrm{NaOH}$ also makes the hot draining of SWRP unattractive.

\section{INTRODUCTION}

At the request of General Electric;, LMEC sampled and characterized the material which settled to the bottom of the reaction products tank (RPT) after sodium-water reactions occurred in the Large Leak Test Rig (LLTR). The sampling was performed after the fourth sodium-water reaction in the LLTR with the AI-MSG as test article. Approximately $110 \mathrm{lb}(50 \mathrm{~kg})$ of water had been injected into the sodium in the four tests. The products of the reaction in excess of the amount soluble in the sodium settled to the bottom of the RPT. An unknown, but probably large, amount of the reaction products remained in the AI-MSG and interconnecting piping.

The purpose of the sampling and characterization program was to obtain experimental data which could be used to evaluate potential techniques for removing sodium-water reaction products (SWRP) from RPT's in large sodium reactor systems. The effort fell naturally into two parts, sampling and characterization, which are discussed in the following sections.

*GE Letter XL-791-01130, T. R. Sandke to S. G. Harbison, "LLTR Reaction Products Tank Deposit Characterization, General Electric Specification N023A2244" (May 12, 1977) 


\section{SAMPLING}

The sampling tool shown in Figure 1 was designed and fabricated. The procedure followed was designated LLTR-SP-016, and is included as Appendix A. The tool was fastened to the end of a piece of pipe about $30 \mathrm{ft}$ long, in order to reach the bottom of the RPT, and rotated by means of a "T" handle at the end of the pipe. Figure 1 is a drawing of the sampling assembly. Photographs of the separated sampling tool are included in Appendix B.

Because it appeared to the operating personnel, by the "feel" of the tool as it was rotated into the deposit on the tank bottom, that the SWRP layer was only an inch or two thick, the tool was lifted and lowered in a nother spot three times. A sample weight of a pound or more was desired. The procedure used produced a sample that weighed about $1-1 / 2 \mathrm{lb}$.

During sampling, there was a layer of liquid sodium about $4 \mathrm{ft}$ deep above the settled SWRP. This sodium was maintained at a temperature of $350^{\circ} \mathrm{F}$ $\left(177^{\circ} \mathrm{C}\right)$ for most of the time between sodium-water reaction tests, and during the sampling of the SWRP. During the removal of the sampler from the RPT, the sodium clinging to it caught fire before the device could be cooled sufficiently to freeze the sodium to permit completion of the bagging. The burning sodium was removed from the outside of the sampler with no apparent effect on the contained sample. After removal of the $30-\mathrm{ft}$ pipe, the sampler body was transported in an argon-filled plastic bag to the chemistry laboratory.

\section{CHARACTERIZATION}

Characterization and analysis of the SWRP sample was carried out by the LMEC Chemical and Metallurgical Laboratory, using the specially written LMEC Procedure C\&M-SP-002. The procedure and the detailed results of the characterization and analysis are included in Appendix B. The discussion which follows provides an interpretation of the results. 


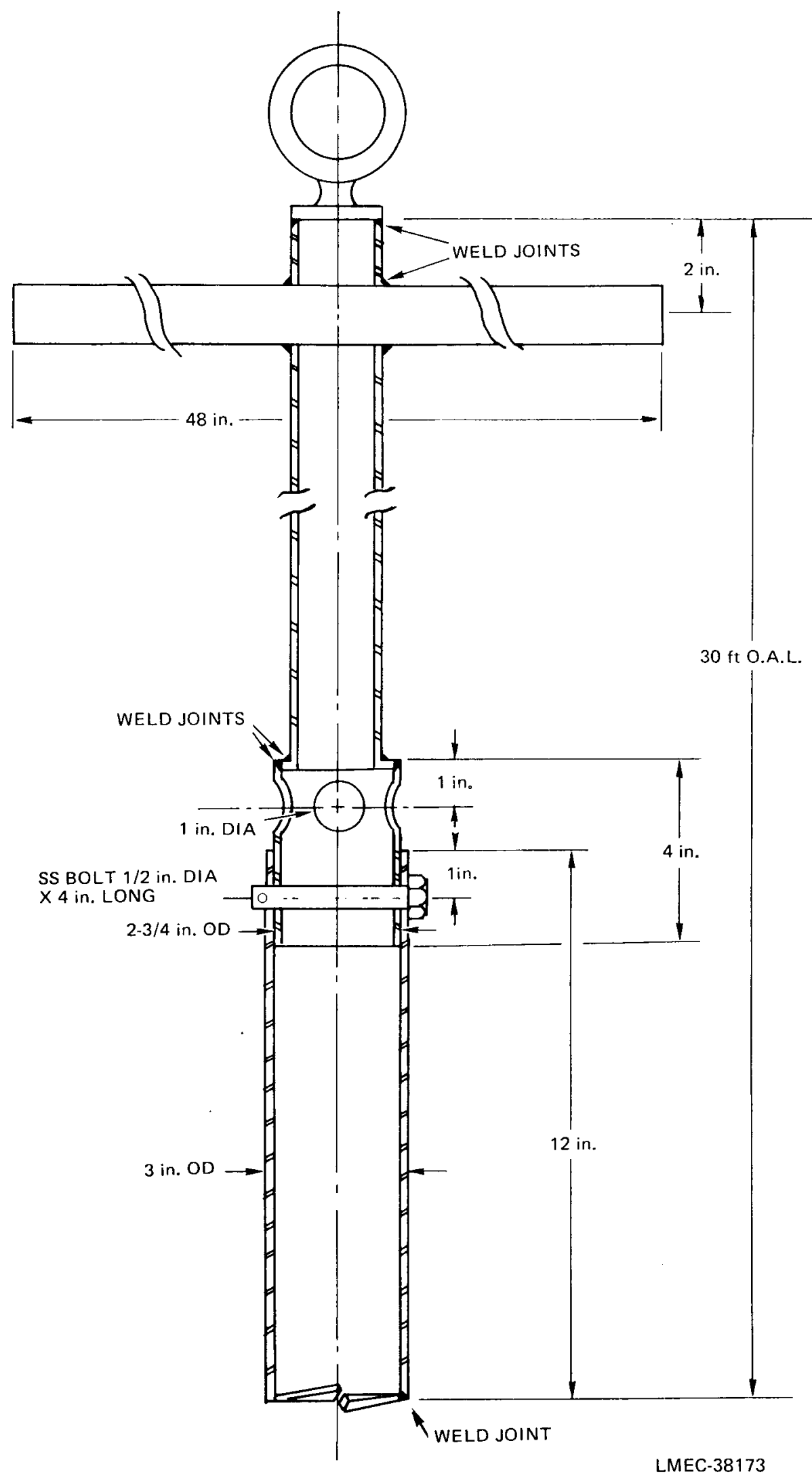

Figure 1. Sample Collector Assembly

LMEC-77-7 


\section{DISCUSSION}

The results of the characterization and analysis of the sampled SWRP are described in detail in LMEC Chemical Analysis Report No. 3719, which is included in Appendix B. The X-ray diffraction patterns show that the compounds present in the SWRP are $\mathrm{Na}_{2} \mathrm{O}, \mathrm{NaOH}$, and $\mathrm{NaH}$, in addition to unreacted elemental sodium. These three compounds cannot all be in thermodynamic equilibrium with liquid sodium. This circumstance would be a violation of the Phase Rule. The $\mathrm{Na}-\mathrm{O}-\mathrm{H}$ system has been carefully examined thermodynamically by Jansson ${ }^{* *}$ and compared with experimental results from many sources. The equation,

$$
\mathrm{NaOH}(\mathrm{s}, \ell)+2 \mathrm{Na}(\ell)=\mathrm{Na}_{2} \mathrm{O}(\mathrm{s})+\mathrm{NaH}(\mathrm{s}),
$$

was found to move to the left above $707 \mathrm{~K}\left(813^{\circ} \mathrm{F}\right)$ and to the right below that temperature, theoretically. Experimentally, the temperature at which the four condensed phases can coexist was found to be somewhat lower, about $680 \mathrm{~K}\left(764^{\circ} \mathrm{F}\right)$. This means that, at equilibrium, solid $\mathrm{NaOH}$ (m.p. 592K, $606^{\circ} \mathrm{F}$ ) cannot coexist with liquid sodium. If the system had been permitted to $\mathrm{reach}$ equilibrium at the temperature of the sodium-water reaction in the AI-MSG, there should be no sodium oxide or hydride present. On the other hand, if the system had reached equilibrium at the temperature of the RPT, there should be no sodium hydroxide found.

Obviously, the composition of the sampled SWRP depends on its time and temperature history following the sodium-water reaction. The SWRP from some other system, or from the LLTR R PT following tests at different conditions, would contain the same compounds, but would not necessarily have the composition of any of the samples examined here.

The distribution of the various compounds found in the sample contained in the sampler is not thought to be significant, nor indicative of the distribution in the SWRP layer in the RPT. The layer in the tank seems not to be hard, but

*Sven A. Jansson, "Thermochemistry and Solution Chemistry in the SodiumOxygen-Hydrogen System," in Corrosion by Liquid Metals, J. E. Draley and J. R. Weeks, eds. (Plenum Press, New York N.Y. 1970) 
instead to have the consistency of very wet sand. Therefore, the sample removed from the tank by the sampler did not end up as discrete layers.

The oxygen analyses by mercury amalgamation show reasonable agreement in one case and poor agreement in two cases, when compared to the composition of samples from the same sections of SWRP, found by X-ray diffraction. Because of the lack of homogeneity in the sample and the rather wide limits of uncertainty in the $X$-ray analysis, this circumstance is not troubling. The amalgamation reflux analyses for hydrogen agree reasonably well with the amount of hydrogen in the sodium hydride reported by $\mathrm{X}$-ray diffraction.

The amount of sodium lost in the distillations is in the range found by $X-r a y$ diffraction. The analysis of the distillation residues shows that the $\mathrm{NaH}$ has been decomposed under heat and vacuum, as is expected, and that some of the $\mathrm{NaOH}$ has reacted with sodium in the process to give $\mathrm{Na}_{2} \mathrm{O}$ and hydrogen.

The dissolution of SWRP in ethanol was rapid and complete, with the generation of substantial heat. In Dowanol PM (propylene glycol methyl ether), the solution rate was somewhat slower, and an insoluble residue of $\mathrm{NaOH}$ remained. Distillation residue from the SWRP dissolved more readily in both solvents than the SWRP.

A magnetic, metallic residue remained from dissolution of SWRP or distillation residue in both solvents. This material was found to have the $X-\mathrm{ray}$ diffraction pattern of alpha iron, which is iso-structural with the Croloy - 2-1/4 of which the AI-MSG is made. This is, therefore, probably debris arising from the sodium-water-steel interaction during the sodium-water reaction.

The heating of the SWRP in an attempt to find a "melting" point for it showed that the material does not become fluid at $550^{\circ} \mathrm{F}\left(288^{\circ} \mathrm{C}\right)$, the highest temperature reached in the glove box-hot plate test. The hot mass could be shaped rather easily, but it did not flow. Heating to $800^{\circ} \mathrm{F}\left(427^{\circ} \mathrm{C}\right)$ in a closed system did not result in a homogeneous liquid either. Although visibility in the system was not as good as it was in the glove box melting test, it was evident that a substantial quantity of unmelted material remained after the sodium and sodium hydroxide had melted. 


\section{CONCLUSIONS}

Sodium water reaction products which are separated in the LLTR reaction products tank are a nonequilibrium mixture of sodium hydroxide, sodium oxide, sodium hydride, and sodium. It does not seem feasible to liquefy the SWRP by heat at a temperature below $800^{\circ} \mathrm{F}\left(427^{\circ} \mathrm{C}\right)$. Because of the highly corrosive behavior of liquid $\mathrm{NaOH}$ toward steel, it is unwise to heat the SWRP above the melting point of $\mathrm{NaOH}\left(606^{\circ} \mathrm{F}, 319^{\circ} \mathrm{C}\right)$ in a steel vessel. The rapid and complete solubility of SWRP in ethanol leads to the conclusion that this solvent should be tested more completely as a cleaning agent for sodium systems which a re contaminated with water reaction products. Dowanol PM also shows promise for this use, but the lower solubility of $\mathrm{NaOH}$ in it makes it less attractive. 
APPENDIX A

PROCEDURE FOR SAMPLING

SODIUM-WATER REACTION PRODUCTS

IN LLTR RPT

LMEC- 77-7

13 
LLTR-SP-016

Page 01

July 21, 1977
No. TI-45-LME-011

Page 10 of 41

Date $\frac{10 / 13 / 77}{10 / 7}$

SAMPLE REMOVAL OF SODIUM-WATER REACTION

PRODUCTS (SWRP) FROM THE REACTION PRODUCTS

TANK (RPT) IN THE LARGE LEAK TEST RIG (LLTR)

Approvais: $Q$ R. E. Echallerger 7/21/17

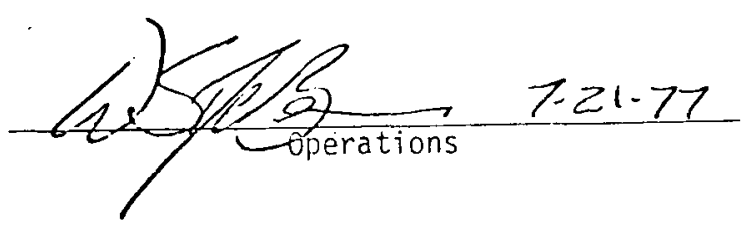


LLTR-SP-016

Page 02

Juiy 21, 1977
No. TI-45-LME-011

Page 1 of 41

Date: $\overline{10 / 13 / 77}$

I. PURPOSE

The purpose of this procedure is to provide instructions for the removal of an SWRP sample from the bottom of the RPT in order to perform chemical analysis on the SWRP

formed as a result of SWR tests one through four.

II. METHOD

A special tool has been fabricated to be used to try and remove SWRP material from the bottom of the 25 foot deep RPT. The tool will be inserted through the manhole on the top of the RPT while the sodium is at $300 \mathrm{~F}$. A constant cover gas purge will be maintained in the RPT to minimize the influx of oxygen during the sample removal. The tool

will be inserted into the sodium pool and rotated when contact is made with the SWRP concentration near the bottom of the RPT. When contact with the bottom of the tank has been made, the sample tool will be raised and allowed to cool prior to removal from the RPT. When the sample has cooled to room temperature, it will be removed from the RPT, and the fixture handle, and placed in a plastic bag for shipment to the Chem. Lab. at LMEC for analysis.

\section{REFERENCE}

1. GE Letter requesting sample of SWRP for series one tests one through three. Number XL-791-01130 F2648 (Y4), DRF -1971 .

\section{TEST EQUIPMENT}

1. Special tool designed for SWRP removal.

2. Plastic bag for shipment of sample. 
LLTR-SP-016

No. T1-45-LME-011

\section{v. SYSTEM LIMITS}

\section{None.}

\section{PROCEDURE}

1. Shift Leader approval to start procedure.

\section{Shift Leader}

2. Verify that the sample tool is clean.

3. Remove or verify that the decanter assembly has been removed from the RPT.

4. Verify that there is enough $\mathrm{N}_{2}$ in the NS to maintain the purge on the RPT while the manhole cover is off for sample removal.

5. Verify that the manhole cover and any instrument leads have been removed permitting easy access for the sample tool.

6. Fabricate and install a plastic bag on the manhole flange. Bag should be approximately 6 to 8 feet iong.

\section{NOTE}

The bag will be used to contain some of the RPT purge and also to make a cooling chamber for the sample as it is removed from the vessel.

7. Connect the sample tool to the overhead crane and lower it into the RPT through the piastic bag. 
LLTR-SP-016

Page 04

July 21, 1977
No. TI-45-LME-011

Page 13 of 41

Date $10 / 13 / 77$

Date/Initial

\section{NOTE}

The handle of the sample tool may have to be trimmed in order to fit through the hole in the main deck.

8. When the sample tool has been lowered into the RPT, then close the bag around the shaft enough to minimize cover gas leakage. Leave the bag top loose enough so the sample tool can still be rotated to obtain a sample.

9. Start rotating the sample tool clockwise as soon as contact is made with the SWRP.

10. Stop rotating the sample tool when the bottom of the RPT is contacted.

11. Raise the sample tool above the sodium pool and let the sample cool to cover gas temperature.

12. When the sample has cooled to cover gas temperature, raise it into the plastic bag just above the RPT and let it cool to room temperature.

13. When the sample has cooled, remove it from the sample tool handle, place it in a plastic bag and send it to the Chem. Lab. for analysis.

14. Remove the plastic bag and replace RPT manhole cover.

15. Shift Leader sign-off procedure complete. 


\section{APPENDIX B \\ CHARACTERIZATION OF SWRP \\ SAMPLE, PROCEDURE, AND RESULTS}

LMEC-77-7 
No. $T I-45-1 M E-011$

Page 15 of 41

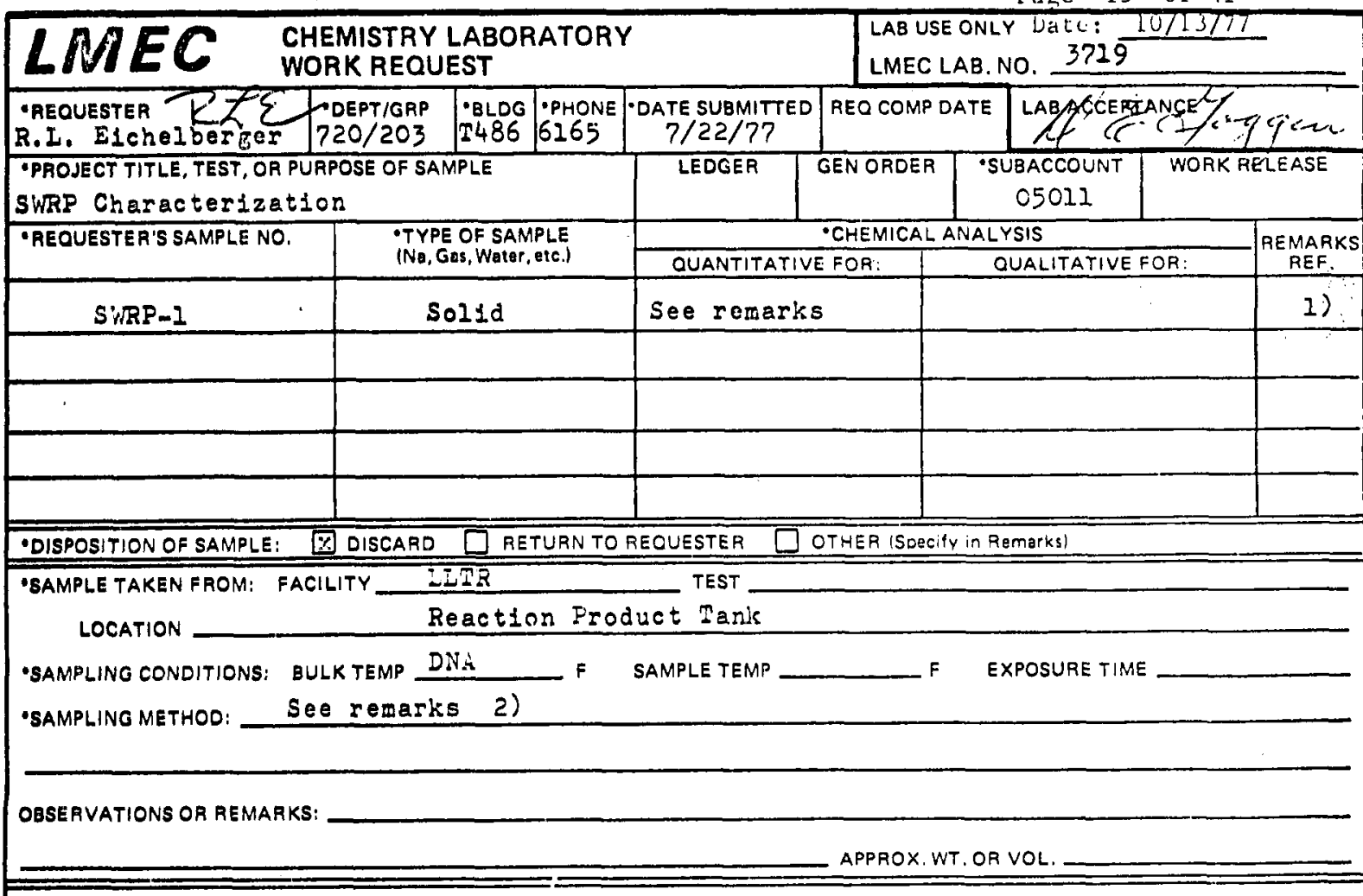

ANALYSIS TO VERIFY SAMPLE MEETS: PURCHASE CRDER NO.

OR SPECIFICATIONS

"ADDITIONAL DISTRIBUTION OF CHEMICAL ANALYSIS REPORT

TO: (Name, Dept., Bldg.)

REQUESTER'S REMARKS:

1) Analyze per C+M-SP-002.

2) Sampling conducted per ILTR-SP-016.

LMEC LABORATORY ACTION (LAB USE ONLY)

Refer to Met Lab Work Request \#743 for documentation photographs.

- Items so marked are to be completed by Ronuester; other information is optional.

FORM 73S-A.35 REV 1.73

REPORT COPY

LMEC- 77-7 
No.TI-45-LME- 011

Page $-\frac{16}{10 / 13 / 77}$

$\mathrm{C}+\mathrm{M}-\mathrm{SP}-002$

Page 01

$7 / 21 / 77$

SPECIAL PROCEDURE -

LLTR REACTION PRODUCTS TAKK DEPOSIT

CHARACTERIZATIOS

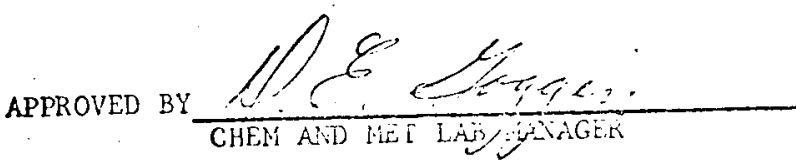

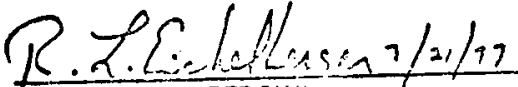

LMEC ENGINEERINY

LMEC- 77-7 
No. $\frac{T I-45-L M E-011}{17 \text { of }}$

rage 17 of 4 !

$\mathrm{C}+\mathrm{M}-\mathrm{SP}-\mathrm{OO} 2$

Late $- 1 0 / 1 3 \longdiv { 7 7 }$

Page 02

$7 / 21 / 77$

\section{PUPPOSE}

The purpose of this procedure is to provide an outline of methods for 1) the physical and chemical characterization of LLTE sodiumwater reaction products (SIRRP), 2) testing the reactivity of ShRP with various solvents, and 3 ) measuring the melting point of SikP to satisfy the requirements of General Elcctric Specification No. 22A2244, and agreements and comitments, 77LIEC-DRF-2058.

II. METHOD

1. Prior to delivery of a SURP sample to the LIEC Chom Lab, LUEC Engineering shald. request characterization of the sample per this test plan in accordance with Li:EC Procedure V-105. A Chem Lab hork kequest (CLIR), form 735-A-35, shall be subnittad for approval by the Chemical and Metallurgical Laboratory Yanager, or his designee.

2. LMEC Engineering shall maintain cognizance over sampling activities, and shall furnish the Chenical Laboratory with the SWRP sample.

3. Upon receipt of the SWRP sample, LNEC Chamical Latoratozy shail conduct its characteriation in accorbance with this special procedure.

4. Chemical Laboratory shall document results per LME Procedure v-105 on Chemical Analysis Report form 735-A-34. Two copies of this form and form $735-A-35$ will be distributed to LNC Engineering upon their completion.

\section{PREREQUISITES}

LWEC Engineering shall initiate and be cognizant over sampling activities and the delivery of a suitable sample of SlRR to the Chemical Laboratory.

\section{REFERENCES}

1. General Electric Specification No. $23 A 2244$, attaclinent to DRF- 1971 .

2. LNEC Procedure V-105

3. 77LAEC.-DRF -2058

4. RDT F3-40T 
v. PROCEDURE: CHARACTERIZATIOIV OF SWRP

\begin{tabular}{ll} 
No. TI-45-LME-011 \\
$\begin{array}{ll}\text { C+M-SP0002 } \\
\text { Page 03 } \\
7 / 21 / 77\end{array}$ & Date $10 / 13 / 77$ \\
\hline
\end{tabular}

1. Sample handling upon receipt of sample by the Chemistry Laboratory.

1.1 Introduce sample into glovebox.

1.2 Photograph

1.3 Weigh total sample

1.4 Probe sample - separate into readily identifiable like parts.

1.4.1 Photograph each part

1.4.2 Describe each part

1.4.3 Weigh each part

2. Sample analysis

2.1 XRD or each separatcd part

2.1.1 Look for all identifiable crystalline phases with eriphasis on $\mathrm{Na}, \mathrm{NaOH}, \mathrm{Na}_{2} \mathrm{O}$, and $\mathrm{Nal}$.

2.1.2 Perform semiquantitative analysis based on comparison of peak height intensities of stronsest peaks of each component with those of a common internal standard (Linde "A" $\mathrm{Al}_{2} \mathrm{O}_{3}$ ).

2.2 Oxygen analysis by amalgamation per RDT F3-40T on each separated part.

2.3 Hydrogen analysis by amalgam reflux per RDT F3-40T on each separated part.

2.4 Distillation of Na from each separated part.

2.4.1 Weigh each sample.

2.4.2 Weigh each recovered residue.

2.4.3 Photograph each recovered residue.

2.4.4 XRD analysis of cach recovered residue.

3. Reactivity with solvents. (As-received SWRP). 
No. TI-45-LME-011

Page $\frac{19 \text { of } \frac{41}{10 / 13 / 77}}{\text { Date }}$

$\mathrm{CHM}-\mathrm{SP}-002$

Page 04

$7 / 21 / 77$

v. PROCEDURE: CHARACTERIZATION OF SIRP (Cont.)

-3.1 Room temperature, no agitation. $300 \mathrm{ml}$ solvent, $10-20 \mathrm{~g}$ SWRP.

3.1.1 Denatured cthano1.

3.1.2 Dowano1 PM.

3.2 Elevated temperature, no agitation.

3.3 Elcvated temperature with agitation.

3.4 Room temperature with water addition.

3.5 Repeat steps 3.1. throus 3.4 using residues from distillation (2.4.2).

4. Melting characteristics.

4.1. Prejininary deiermination, as-received SWR. Use hot plate, surface thermometer, crystallizing dish, metal dial-type thermometer in sample, sample it giovobor.

4.2 Preliminary determination, separated fractions. (Repeat 4.1)

4.3 Repeat 4.1 and 4.2 using pyrex funnel and funnel heating mantle, if warranted.

5. Data Recording

Al1 observations and measurements shall be recorded in LMEC Data Logbooks.

Results shall be reported per this Special Procedure, Section II. 4. 


\section{Liquid Metal Engineering Center CHEMICAL ANALYSIS REPORT}

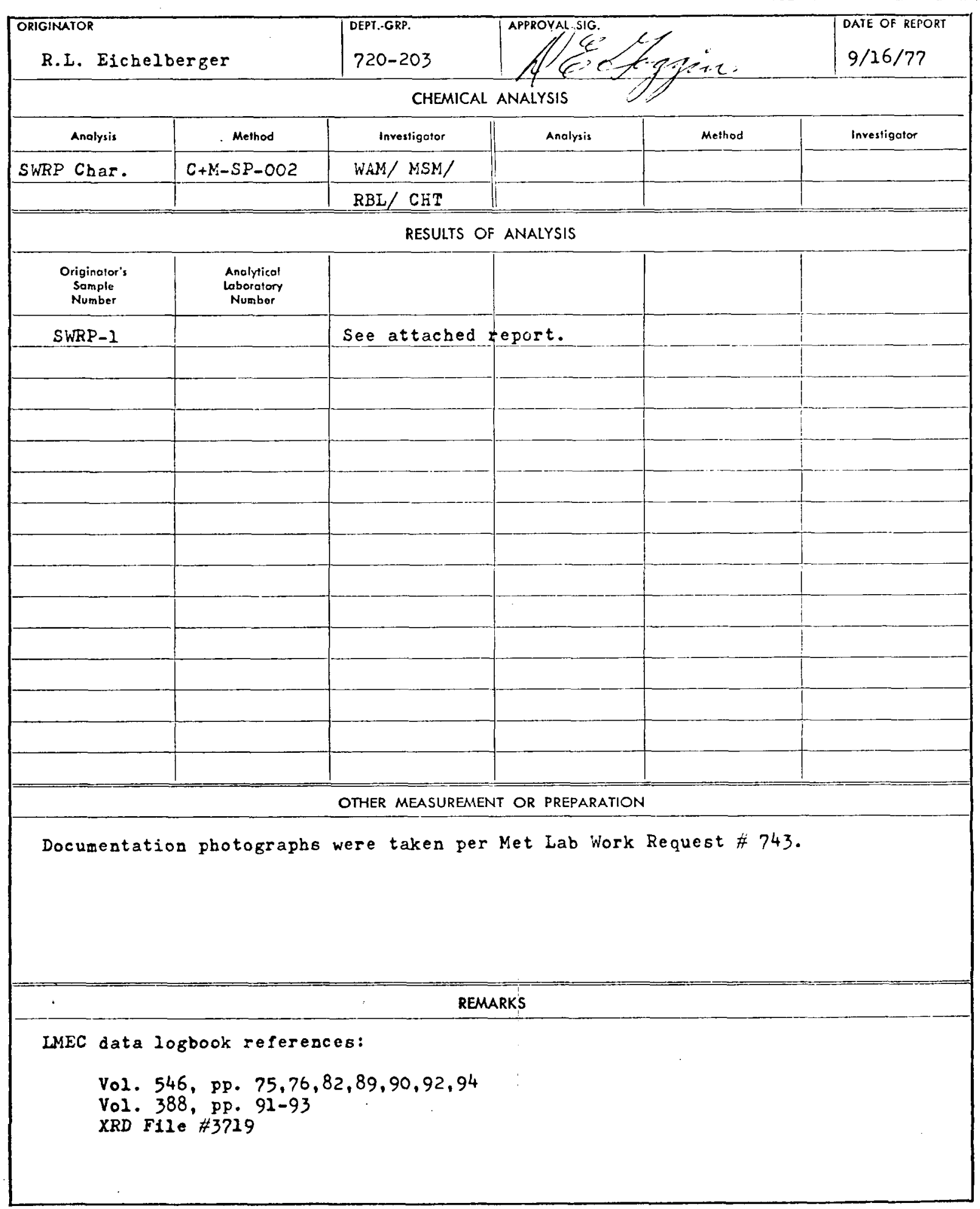

No. TI-45-I.ME-011

Date $1 0 / 1 3 \longdiv { 4 7 }$

REQUEST NO 3719
Paze 20 of 41

FORM 738.A.34 NEW 0.68

LMEC-77-7 
No. $\mathrm{T} I-45-1 M E-011$

-1- $\quad$ Page $\frac{21 \text { of } 41}{10 / 13 / 77}$

ATTACHMENT TO LMEC CHEMICAL ANALYSIS REPORT \$3719

Subject: Characterization of Sodium-Water Reaction Products

Reference: CSM-SP-002, Part V.

\section{INTRODUCTION}

This attachment reports the data and observations obtained in the characterization of a sample of sodium-water reaction products (SWRP) taken from the LLTR reaction products tank on 7-25-77 according to special procedure I.LTR-SP-006. The system of numbering used herein corresponds exactly to that which appears in the referenced procedure.

CHARACTERIZATION OF SWRP

1. Sarrple handling. The SwRP material in its sanpling tool was received in a nitrogen-purged and sealed polyethylene bas.

1.1 The SWRP sample, as-received, was opened in a glove box and renoved from the sampling tool. The single solid sample of SWPP ineasured 2 inches in diameter at the top, $23 / 4$ inches in diameter at the bottom, and was 7 inches high.

1.2 Photographs:

743-1 Head section of SwiRp sampler (in glove box).

743-3 Top view into sampler.

743-5 Bottom view of sampler.

743-6 ShRP sample after removal from sampler (side view).

743-7 SWRP sample (bottom view).

743-8 SWRP sample (top view).

1.3 The SWRP sample weighed 673 grams.

1.4 The solid SWRP sample appeared uniformly grey on its surface. The cylindrical-shaped sample was cut lengthwise into halves using the edge of a spatula. One half was cut into upper and lower sections. The other half was cut into upper, center, and lower sections.

1.4.1 Photographs:

743-9 SWRP sample sectioned into five parts.

743-10 Cross-section of SWRP near bottom showing inclusions.

1.4.2 The SWRP sample had the "feel" of sodium in cutting, except that it was noticeably "gritty" and somewhat harder toward the bottom. Many white and dark inclusions appear within the sodium matrix. (As an example, see photograph 743-10). 


No. TI-45-LiE - OI1
Page 22 of 41
Date $10 / 13 / 77$

1.4.3 The total weight is given in section 1.3. The weights of the various samples taken for analysis are given in the appropriate sections which follow.

2. Sample analysis.

2.1 XRD studies.

2.1.1 Qualitative. Photograph 743-12 shows typical mode of mounting a slice of SWRP sample in $x$-ray sample holder for XRD analysis. All sample handling was done in the glove box. The $x$-ray chamber was sealed in the box atmosphere, and quickly transported to the $x$-ray generator where the sample was scanned under dynamic vacuum. The following crystalline compounds (listed in order of descending peak intensity) were detected:

,

Sample Location* and Crystalline Phases Detected

\begin{tabular}{|c|c|c|}
\hline Section \#l & Section 非 & $\begin{array}{c}\text { Section } 1 / 5 \\
\text { (bottom) }\end{array}$ \\
\hline $\mathrm{Na}$ & $\mathrm{Na}$ & $\mathrm{Na}$ \\
\hline $\mathrm{Na}_{2} \mathrm{O}$ & $\mathrm{Na}_{2} \mathrm{O}$ & $\mathrm{Na}_{2} \mathrm{O}$ \\
\hline $\mathrm{NaOH}$ & $\mathrm{NaH}$ & $\mathrm{NaH}$ \\
\hline $\mathrm{NaH}$ & $\mathrm{NaOH}$ & $\mathrm{NaOH}$ \\
\hline
\end{tabular}

*Location refers to numbering system shown in

photograph $743-9$

2.1.2 Semiquantitative. Several. SWRP samples were prepared for semiquantitative XRD analysis by warming to the melting point of sodium and grinding with an equal weight of Linde "A" alpha aluninum oxide having a one micrometer particle size. Similar standards were prepared using reagent grade sodium, sodium hydroxide, sodium oxide, and sodium hydride. Photograph 743-14 shows a typical preparation. The samples and standards were prepared in the glove box and sealed in the $x$-ray chamber in the box atmosphere as before. Semiquantitative results were obtained by comparing peak intensities of the components in question with those of the aluminum oxide common internal standard. The following results were obtained: 
No. TI -45-LME-011

Page 23 of 41

$-3-$

Date $\overline { 1 0 } / 1 3 \longdiv { 7 7 }$

2.1 .2 (Continued)

\begin{tabular}{|c|c|c|c|c|}
\hline \multirow[b]{2}{*}{ Constituent } & \multicolumn{4}{|c|}{ Wt \% Found in SWRP Sample* } \\
\hline & $\begin{array}{l}\text { Section } \# 1 \\
\text { Center }\end{array}$ & Section & 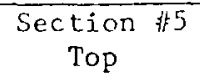 & $\begin{array}{l}\text { Section } \$ 5 \\
\text { Bottom: }\end{array}$ \\
\hline $\mathrm{Na}$ & 47 & 32 & 42 & 60 \\
\hline $\mathrm{Na}, \mathrm{O}$ & 23 & 42 & 23 & 27 \\
\hline $\mathrm{NaOH}$ & 27 & 18 & 31 & 10 \\
\hline $\mathrm{NaH}$ & 3 & 7 & 3 & 3 \\
\hline
\end{tabular}

2.2 Oxygen analysis by amalgamation.

Samples were taken from SWRP Sections $\# 1$, ; 3 , and $\# 5$ for determination of oxygen by the standard amalgamation technique. (See photograph

743-15).

Results are as follows:

\begin{tabular}{l|c|c}
\hline Sample wt. & SWRP Sample & $\begin{array}{c}\text { Wt \% Oxygen by } \\
\text { Amalgamation }\end{array}$ \\
\hline $5.500 \mathrm{~g}$ & Section $\$ 11$ & 6.3 \\
4.015 & Section $\$ 3$ & 6.3 \\
3.020 & Section $\$ 5$ & 8.3 \\
\hline
\end{tabular}

A large amount of oxide residue was observed to float on the mercury during the amalgamation. (See photographs 743-37 and 743-38).

2.3 Hydrogen analysis by amalgam reflux. Samples were taken from SWRP sections 非 2 and $\#^{4} 4$ for determination of hydrogen by the standard amalgam reflux techniques. (See photograph 743-16).

Results are as follows:

\begin{tabular}{l|c|c}
\hline Sample Wt. & SWRP Sample & $\begin{array}{c}\text { Wt \% Hydrogen by } \\
\text { Ama lgam Ref lux }\end{array}$ \\
\hline $2.782 \mathrm{~g}$ & Section \#2 - top & 0.1 \\
2.090 & Section \#14 - centex & 0.09 \\
\hline
\end{tabular}

LMEC-77-7 
No. TI-45-LME-011

Page 24 of 41

Date $\frac{24}{10 / 13 / 77}$

$-4-$

2.4 Distillation of sodium. Two SWRP samples taken from sections 1 l and

\#4 were trimmed of their exterior "skin" and were subjected to dynamic vacuum distillation in tantalum crucibles at pressures of $10^{-3}$ torr.

Photograph 743-23 shows SWRP sample from section 1 l in tantalum crucible before distillation.

Photograph 743-17 shows SWRP sample from section \#4 in tantalum crucible before distillation.

2.4.1 Sample weights:

\begin{tabular}{c|c}
\hline SWRP Sample & Wt. (grams) \\
\hline Section $\# 1$ - bottom & 26.80 \\
Section $\$ 4$ - bottom & 31.46 \\
\hline
\end{tabular}

2.4.2 Residue weights after distillation:

\begin{tabular}{l|c|c}
\hline SWRP Sample & Residue Wt. (grams) & $\begin{array}{c}\text { Residue Wt. } \% \\
\text { of Sample }\end{array}$ \\
\hline Section \#1 & 17.50 & 65.3 \\
Section \#4 & 12.20 & 38.8 \\
\hline
\end{tabular}

2.4.3 Photographs of residues:

743-24 shows residue from section 非.

743-20 shows residue from section 非.

Both residues appeared to be sponge-like and porous in nature. Several

discreet chunks were removed from each residue. The residues could easily be reduced to a fine powder by gentle grinding in the tantalum crucibles.

Photograph 743-25 shows the chunks removed from the SWRP section 非 residue, and the residue after grinding to a fine powder.

Photograph 743-22 shows the chunks removed from SwRP section 非 residue.

Photograph 743-21 shows the SwRP section \#4 residue after grinding to a fine powder. 
No. TI-45-LMF-0 01.1

-5- $\quad$ Page $\frac{25 \text { of } 41}{10 / 13 / 77}$

2.4.4 XRD analysis of SWRP distillation residues. Semiquantitative XRD analysis of the distillation residues was accomplished using the aluminum oxide internal standard technique previously described.

\begin{tabular}{l|c|c}
\hline \hline SWRP Residue & Constituent & Wt. \% Constituent \\
\hline Section \#1 & $\mathrm{Na}_{2} \mathrm{O}$ & 89 \\
& $\mathrm{NaOH}$ & 11 \\
\hline Section $\# 4$ & $\mathrm{Na}_{2} \mathrm{O}$ & 78 \\
& $\mathrm{NaOH}$ & 18 \\
& $\mathrm{Na}$ & 4 \\
\hline
\end{tabular}

In addition, qualitative XRD analysis was done on the large chunks separated from section 非 distillation residue (photograph 743-22).

\begin{tabular}{c|c} 
Shr.P Section $\|_{4}$ Distillation Residue - Chunks \\
\hline Constituent Found & Qualitative XRD \\
\hline $\mathrm{Na}_{2} \mathrm{O}$ & Major \\
$\mathrm{NaOH}$ & Minor \\
$\mathrm{Na}$ & Minor \\
\hline
\end{tabular}

3. Reactivity of SWRP with Solvents.

SWRP samples and distillation residues were reacted with denatured ethanol and Dowanol PM at room temperature in an argon atiosphere.

Their reactions were compared with those of reagent grade sodium under the same conditions. Because of the uncertainty of reaction rates, the experiments were scaled down to approximately single gram samples and $30 \mathrm{~mL}$ of solvent.

3.1 Room temperature, no agitation.

The reactions of SWRP, distillation residues, and sodium with denatured alcohol and with Dowanol PM are sumarized in the following tables:

3.1.1 Reaction with denatured ethanol.

The alcohol was J. T. Baker anhydrous reagent consisting of 95 per cent SDA 3-A alcohol to which has been added 5 volume per cent isopropyl alcohol. Water content was 0.4 weight per cent, determined by the Karl Fischer method. A volume of $30 \mathrm{~mL}$ was used in each case. SWRP and sodium sanples were single, solid pieces. Distillation residue was ground to fine powder. 
No. TI-45-LME-011

Page $\frac{26 \text { of } 41}{10 / 13 / 77}$

$-6-$

Date $\overline{10 / 1} 3 / 7$

\section{1 .1 (Continued)}

\begin{tabular}{|c|c|c|c|c|}
\hline Material & $\begin{array}{l}\text { Wt. taken } \\
(\mathrm{g})\end{array}$ & $\begin{array}{c}\text { Time for } \\
\text { Dissolution } \\
\text { (min) }\end{array}$ & $\begin{array}{l}\text { Max. Temp. } \\
\text { of Solvent } \\
\quad\left({ }^{\circ} \mathrm{C}\right)\end{array}$ & Remarks \\
\hline SWRP & 1.2 & 5 & 46 & $\begin{array}{l}\text { Dark colored } \\
\text { magnetic residue } \\
\text { remained which } \\
\text { was } 0.4 \text { wt } \% \text { of } \\
\text { SWRP sample. } \\
\text { Identified as } \\
\text { alpha iron by XRD. }\end{array}$ \\
\hline $\begin{array}{l}\text { Distilla- } \\
\text { tion re- } \\
\text { sidue } \\
\text { from SWRP } \\
\text { Section } \\
\text { \#4 }\end{array}$ & 1.5 & $\begin{array}{l}\text { Vigorous } \\
\text { reaction* }\end{array}$ & 60 & $\begin{array}{l}\text { Dark colored } \\
\text { magnetic residue, } \\
2.6 \text { wt } \% \text { of } \\
\text { initial sanple. } \\
\text { Identified as } \\
\text { alpha iron by XRD. }\end{array}$ \\
\hline $\begin{array}{l}\text { Sodium, } \\
\text { reagent } \\
\text { grade }\end{array}$ & 0.8 & 62 & 27 & $\begin{array}{l}\text { Clear solution } \\
\text { resulted. }\end{array}$ \\
\hline
\end{tabular}

3.1.2 Reaction with Dowanol PM.

The Dowanol was Dow Chenical propylene giycol methyl ether. Water content was 0.3 weight per cent, determined by the Karl Fischer method. A volume of $30 \mathrm{~mL}$ was used in each case. SWRP and sodium samples were single, solid pieces. Distillation residue was ground to a fine powder. 
No. TI-45-LME-011

Page 27 of 41

Date $10 / 13 / 77$

\subsection{2 (Continued)}

$-7-$

\begin{tabular}{|c|c|c|c|c|}
\hline Material & $\begin{array}{l}\text { Wt. taken } \\
(\mathrm{g})\end{array}$ & $\begin{array}{c}\text { Time for } \\
\text { Dissolution } \\
\text { (min) }\end{array}$ & $\begin{array}{l}\text { Max. Temp. } \\
\text { of Solvent } \\
\left({ }^{\circ} \mathrm{C}\right)\end{array}$ & Remarks \\
\hline SWRP & 1.0 & 6.8 & 94 & $\begin{array}{l}\text { Dark colored } \\
\text { magnetic residue } \\
\text { remained which was } \\
0.9 \text { wt } \% \text { of SWRP } \\
\text { sample. Identified } \\
\text { as alpha iron by XRD. }\end{array}$ \\
\hline $\begin{array}{l}\text { Distilla- } \\
\text { tion re- } \\
\text { sidue } \\
\text { from SWRP } \\
\text { Section } \\
\text { \#4 }\end{array}$ & 1.5 & $\begin{array}{l}\text { Fast re- } \\
\text { action* } \\
\text { (slightly } \\
\text { slower than } \\
\text { with alcohol }\end{array}$ & 40 & $\begin{array}{l}\text { Dark colored } \\
\text { magnetic residue } \\
\text { remained which was } \\
2.5 \text { wt } \% \text { of initial. } \\
\text { sample. Identified } \\
\text { as alpha iron by XRD. } \\
\text { A white precipitate } \\
\text { was observed to form } \\
\text { upon reaction. Prc- } \\
\text { cipitate identified } \\
\text { as NaOH by XRD. }\end{array}$ \\
\hline $\begin{array}{l}\text { Sodium, } \\
\text { reagent } \\
\text { grade }\end{array}$ & 1.1 & $>60$ & 72 & $\begin{array}{l}\text { Clear solution } \\
\text { resulted }\end{array}$ \\
\hline
\end{tabular}

* Powdered distillation residue was added in small increments.

Photographs 743-35 and 743-36 (scanning electron micrographs) show the microscopic nature of the dark colored magnetic alpha iron particles recovered from the SWRP. This material probably represents normal system debris.

3.2 Elevated temperature, no agitation.

3.3 Elevated temperature with agitation.

3.4 Water addition.

Since the SWRP and residue reactions proceeded faster than those of sodium in the solvents used, it was decided to limit the experimentation to conditions of room temperature and no water addition.

3.5 Solvent reactions with distillation residues.

Data have been incorporated in section 3.1 .1 and 3.1.2.

4. Melting characteristics of SWRP.

The behavior of SWRP was observed 1) in pyrex at telliperatures at $550^{\circ} \mathrm{F}$, and 2) in a tantalum. cup at temperatures to $800^{\circ} \mathrm{F}$. In both cases solid 
No. TI-45-1.ML:-011

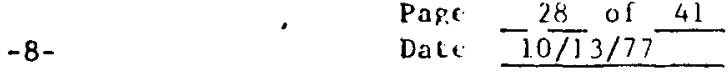

4. (cont' $d)$

and liquid phases were obscrved to be present.

4.1 As-received SWRP.

Photograph 743-26 shows a 15.3 gram sample of SWRP in a pyrex bcaker

at a temperature of $550^{\circ} \mathrm{F}$, the limitation of the hot plate. At this

temperature the SWRP demonstrated a consistency like that of wet sand.

It could be molded with a spatula and retain its shape. (See photo-

graph 743-27, a closer look at the SWRP in beaker). Soljo particles, sand-like in appcarance, were observed throughout the SWRP. This heating was done in the helium atmosphere of a glove box.

Pholograph 743-29 shows a 28.4 graul sample of SwRP which had been heated to $800^{\circ} \mathrm{F}$ in a tantalum cup in a static helium atmosphere at a pressure of about 700 torr. Again, two phases remained. Heating was carried out in temperature increments of $100^{\circ} \mathrm{F}$, and the contents of the tantalum cup were examined visually, to the extent possible, through the glass walls of the containment vessel. The top crust was visible, and it appeared to undergo no change. There was no apparent outgassing of the SkRP during heating as indicated by the lack of any sicnificant increase in system pressure. 


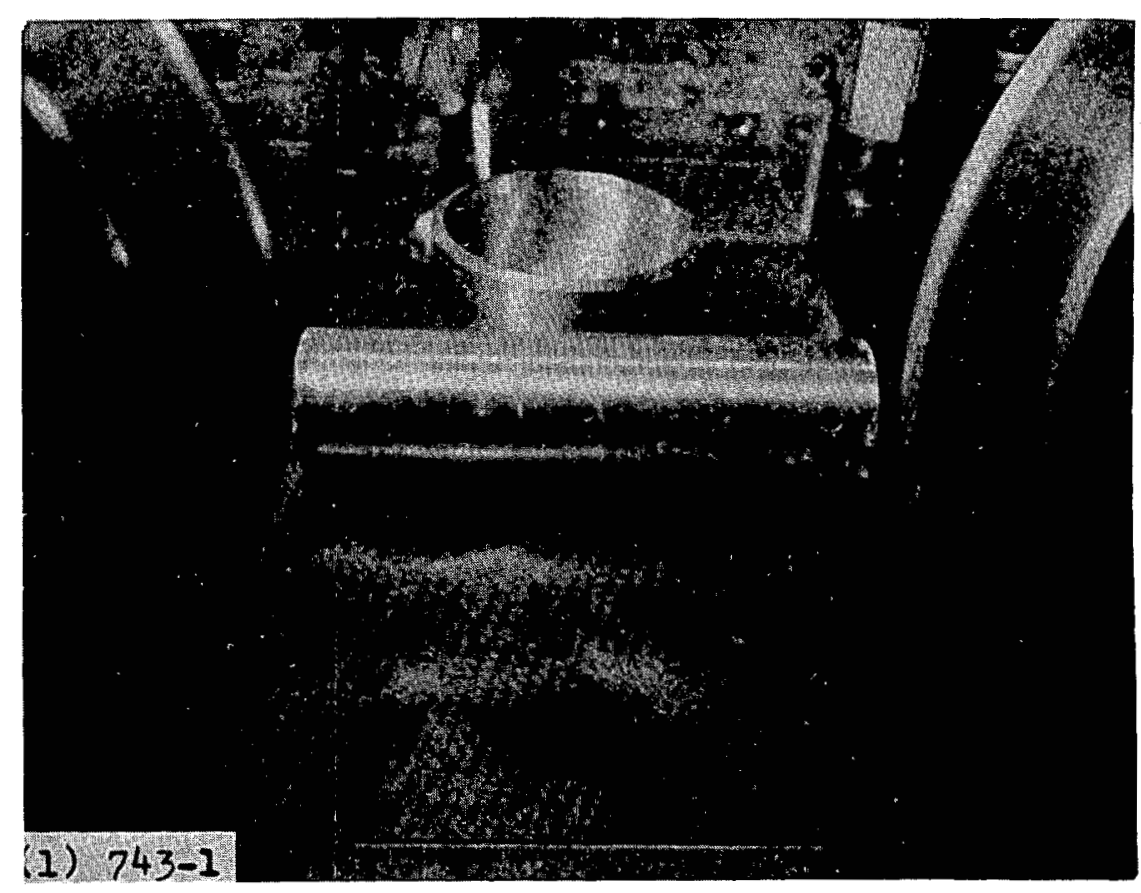

LMEC-P38174

Figure B1. Head Section of SWRP Sampler (in glove box) (743-1)

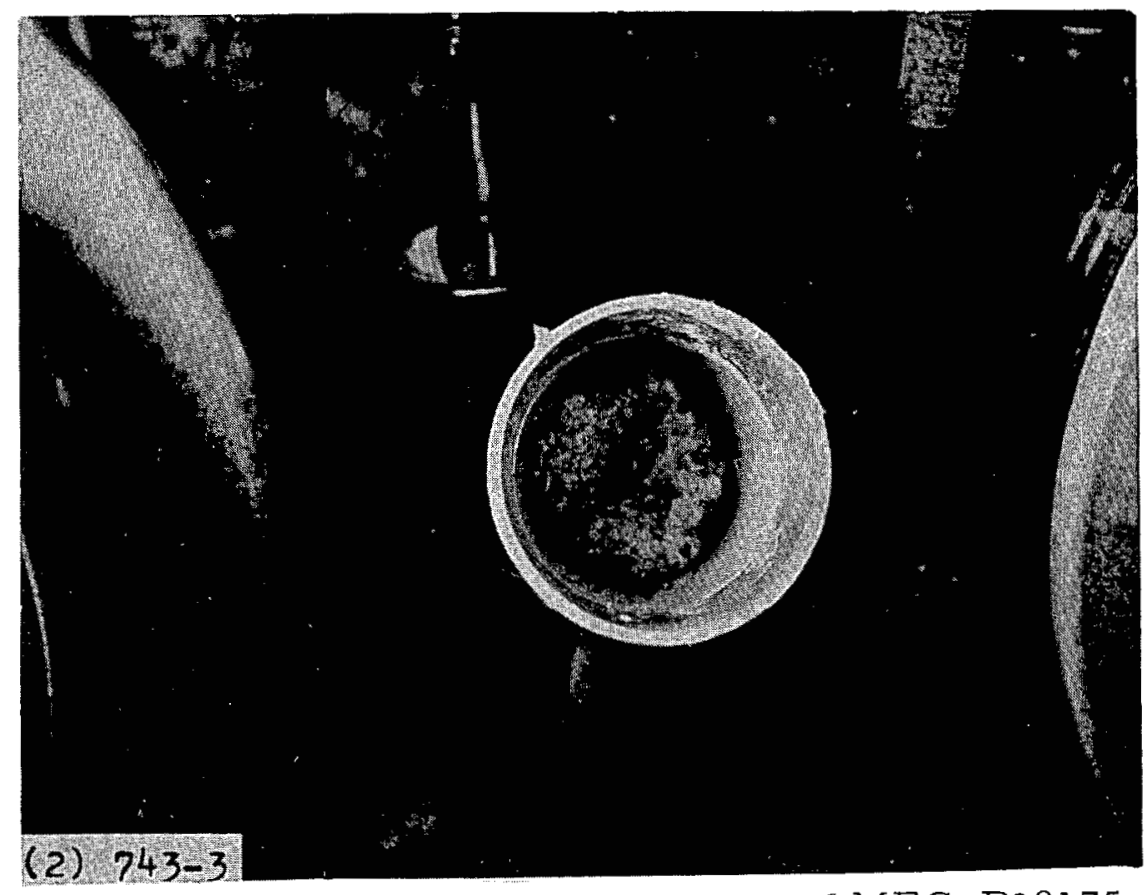

LMEC-P38175

Figure B2. Top View Into Sampler (743-3)

LMEC- 77-7 


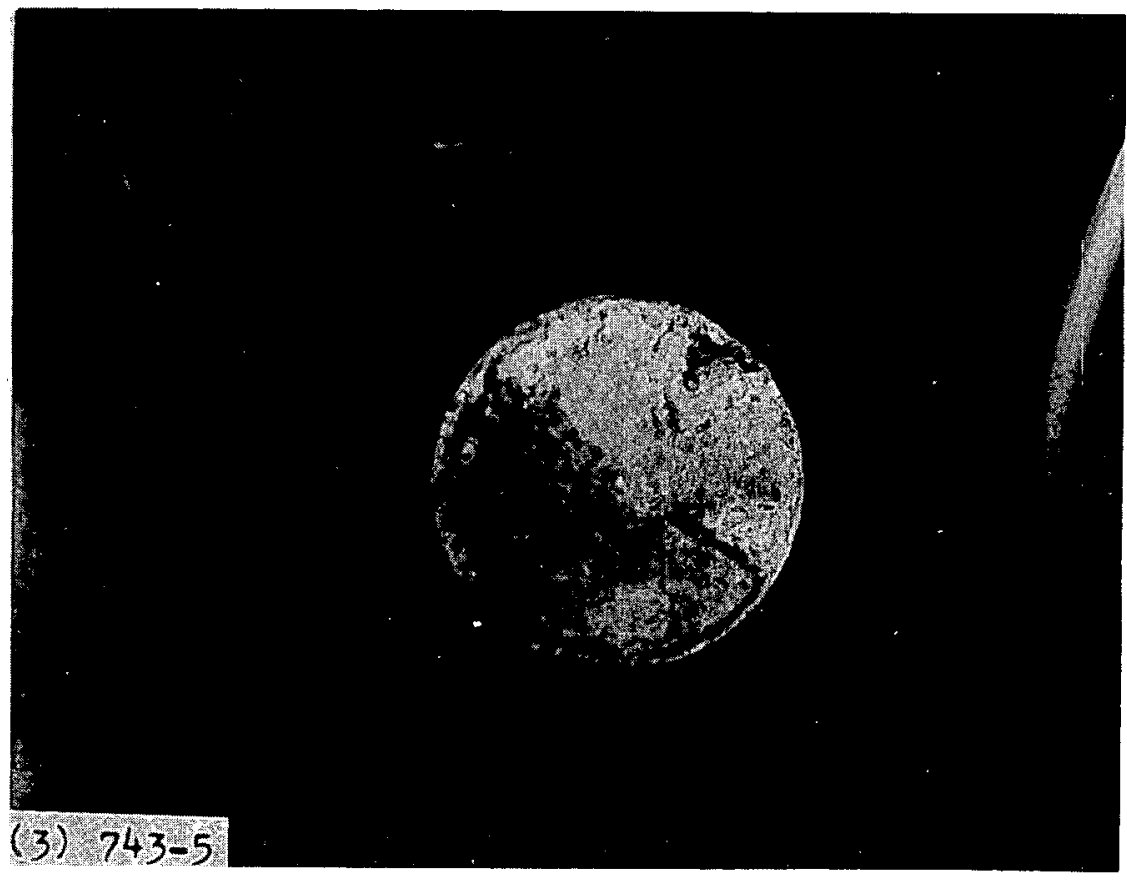

LMEC - P38176

Figure B3. Bottom View of Sampler (743-5)

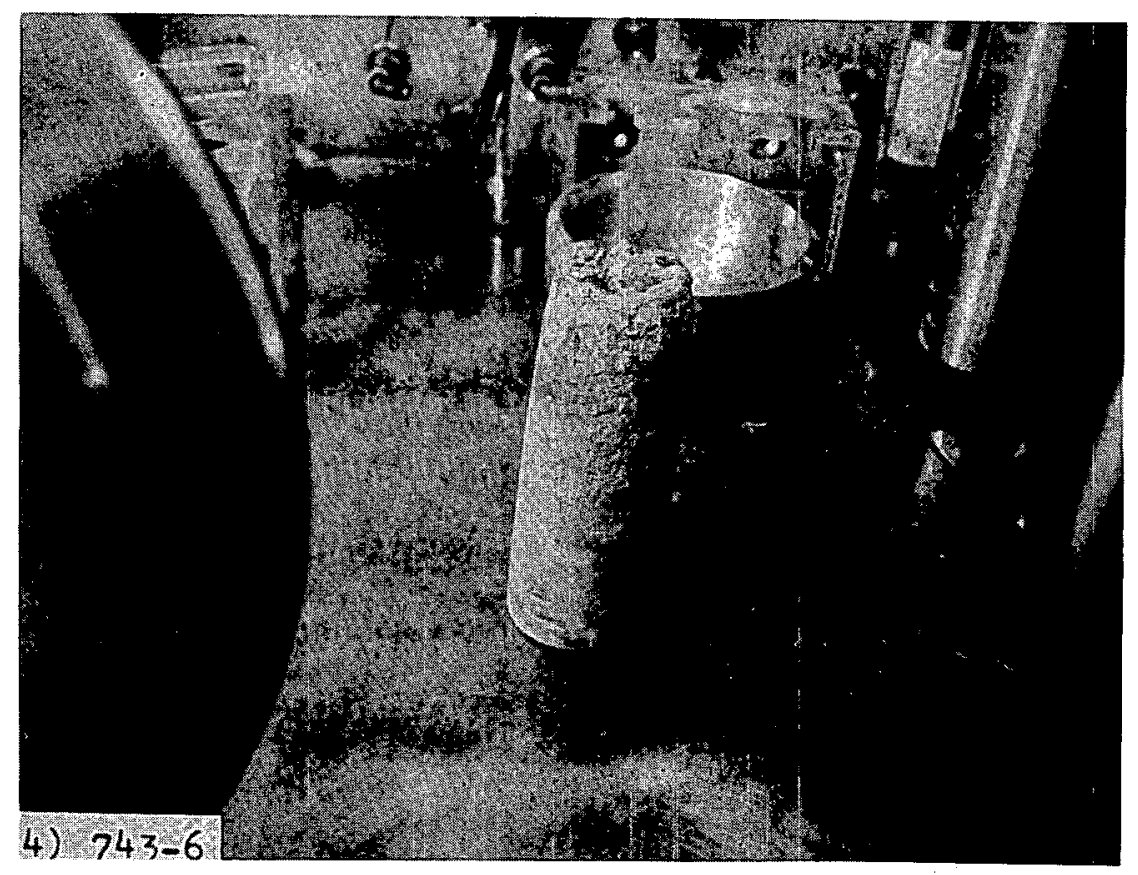

LMEC-P38177

Figure B4. SWRP Sample After Removal From Sampler (side view) (743-6) 


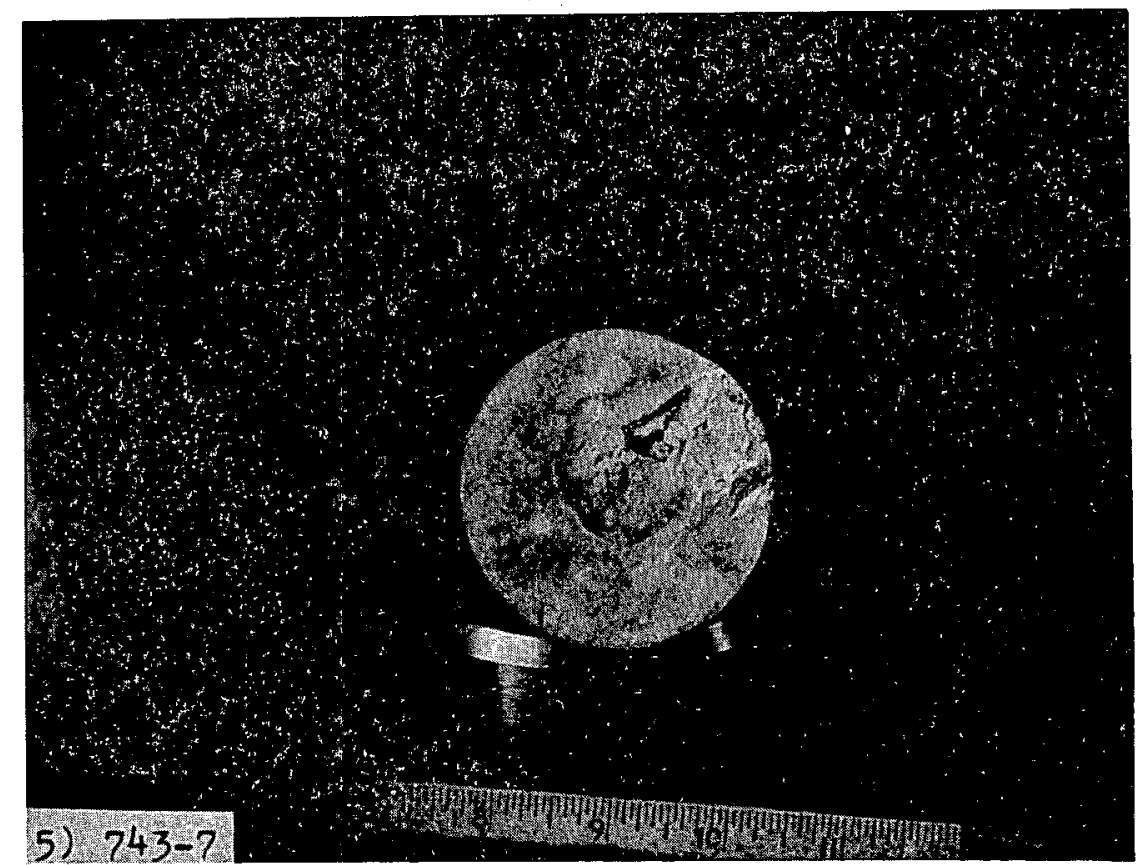

LMEC-P38178

Figure B5. SWRP Sample (bottom view) (743-7)

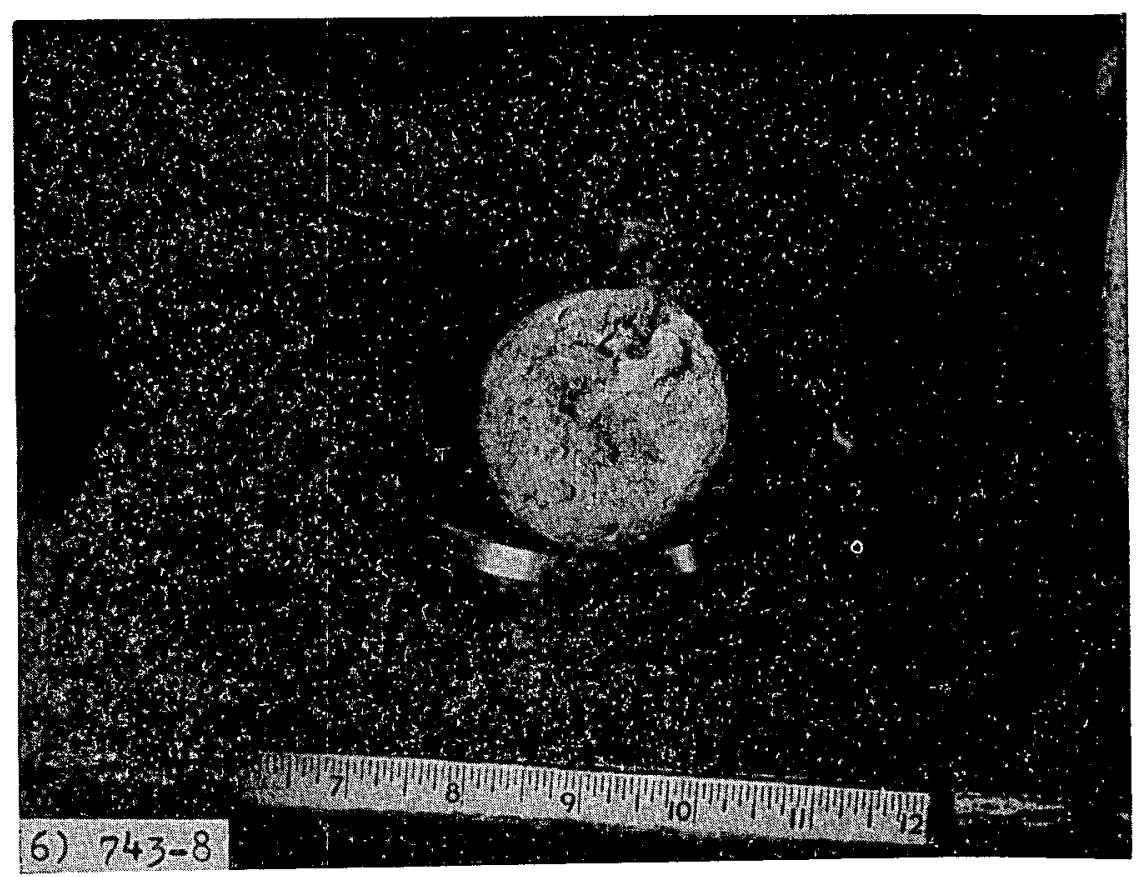

$\overline{\mathrm{LMEC}}-\overline{\mathrm{P}} 38179$

Figure B6. SWRP Sample (top view) (743-8)

LMEC-77-7 


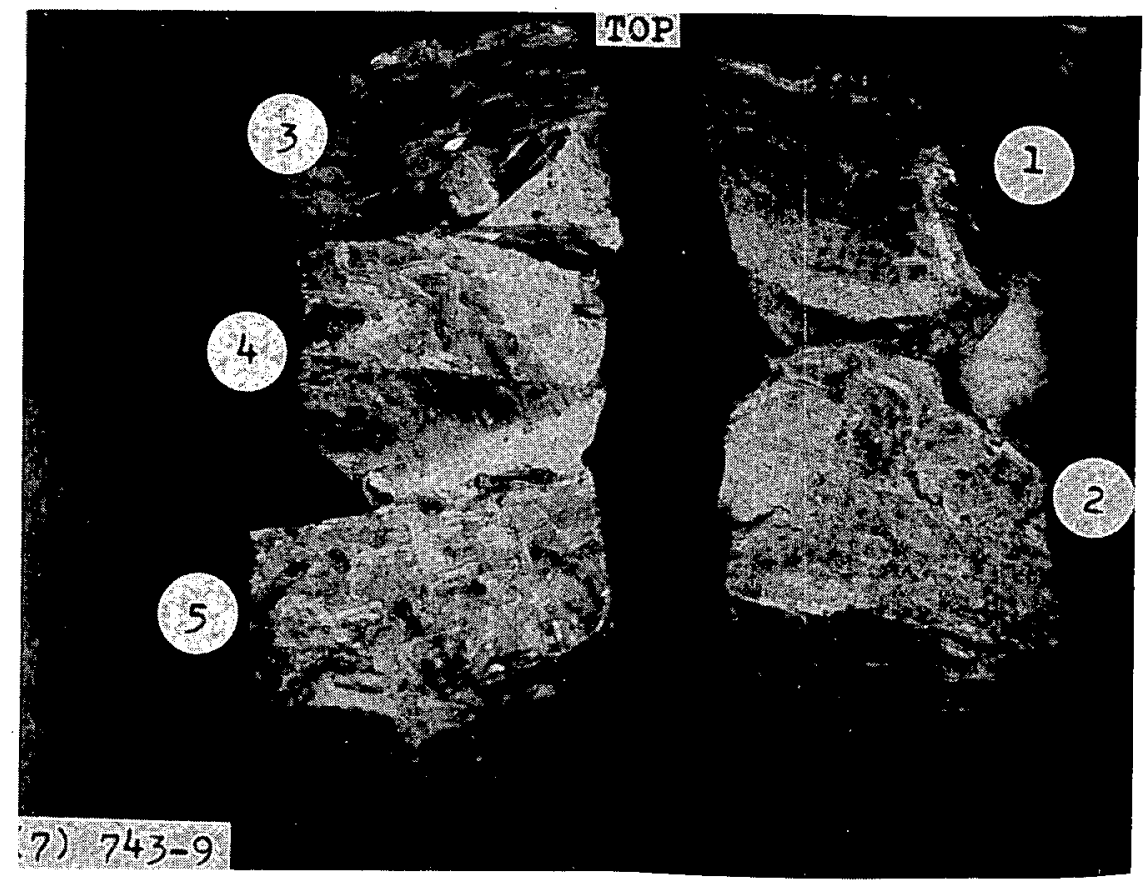

LMEC-P38180

Figure B7. SWRP Sample Sectioned Into Five Parts (743-9)

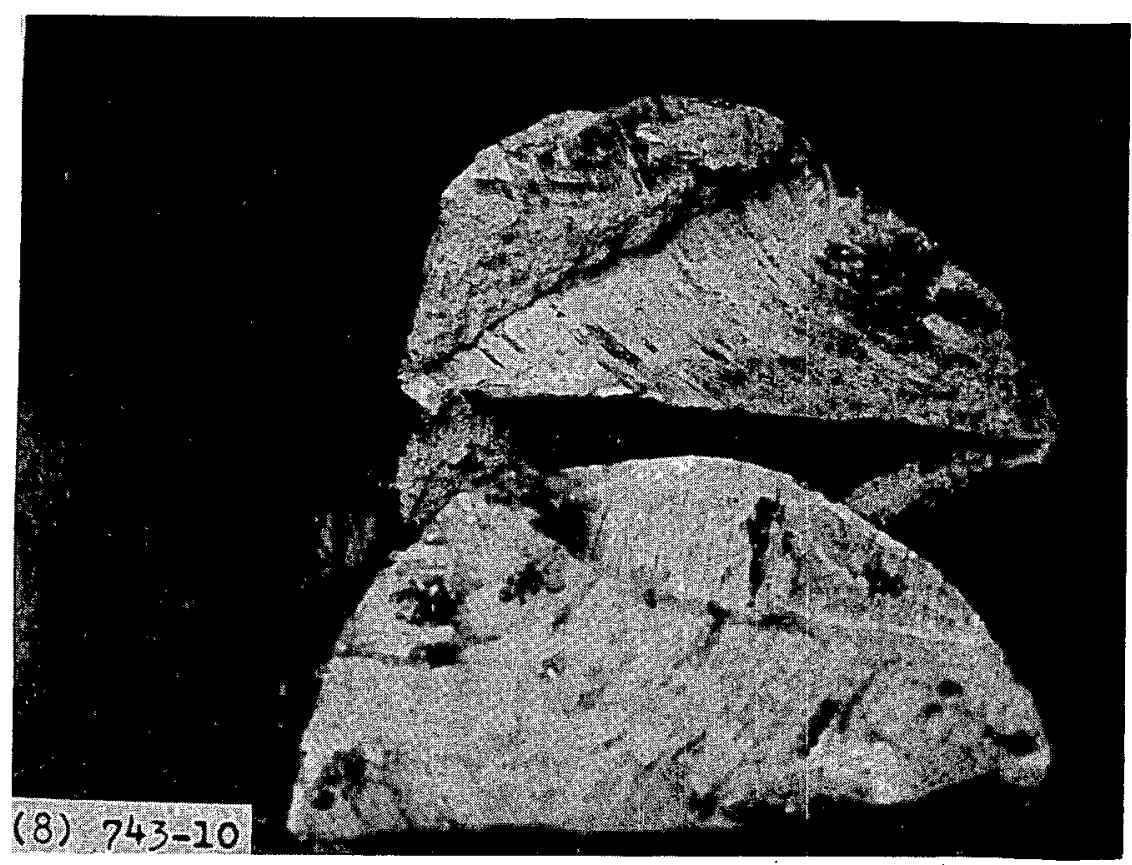

LMEC-P38181

Figure B8. Cross-Section of SWRP Near Bottom, Showing Inclusions (743-10) 


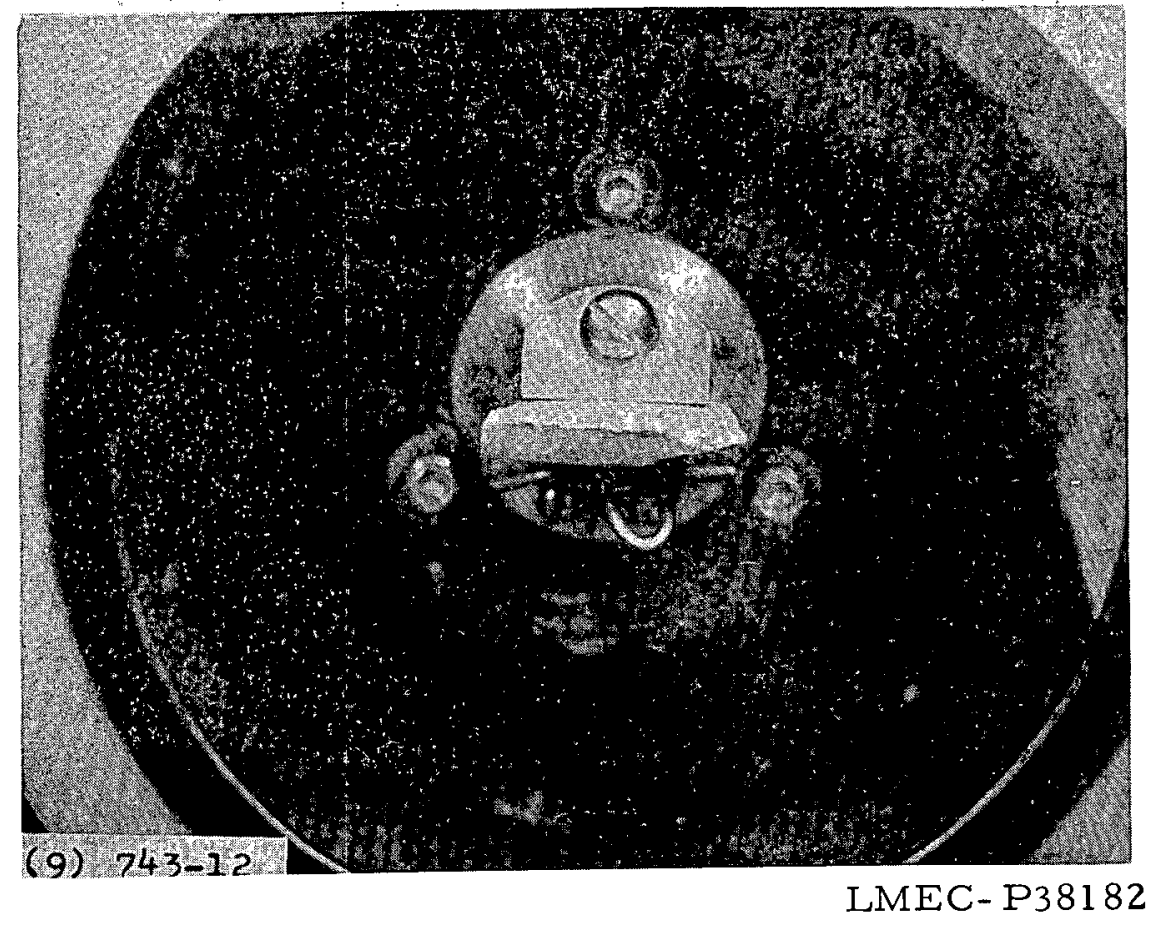

Figure B9. SWRP Sample Mounted in X-ray Diffraction Sample Holder (743-12)

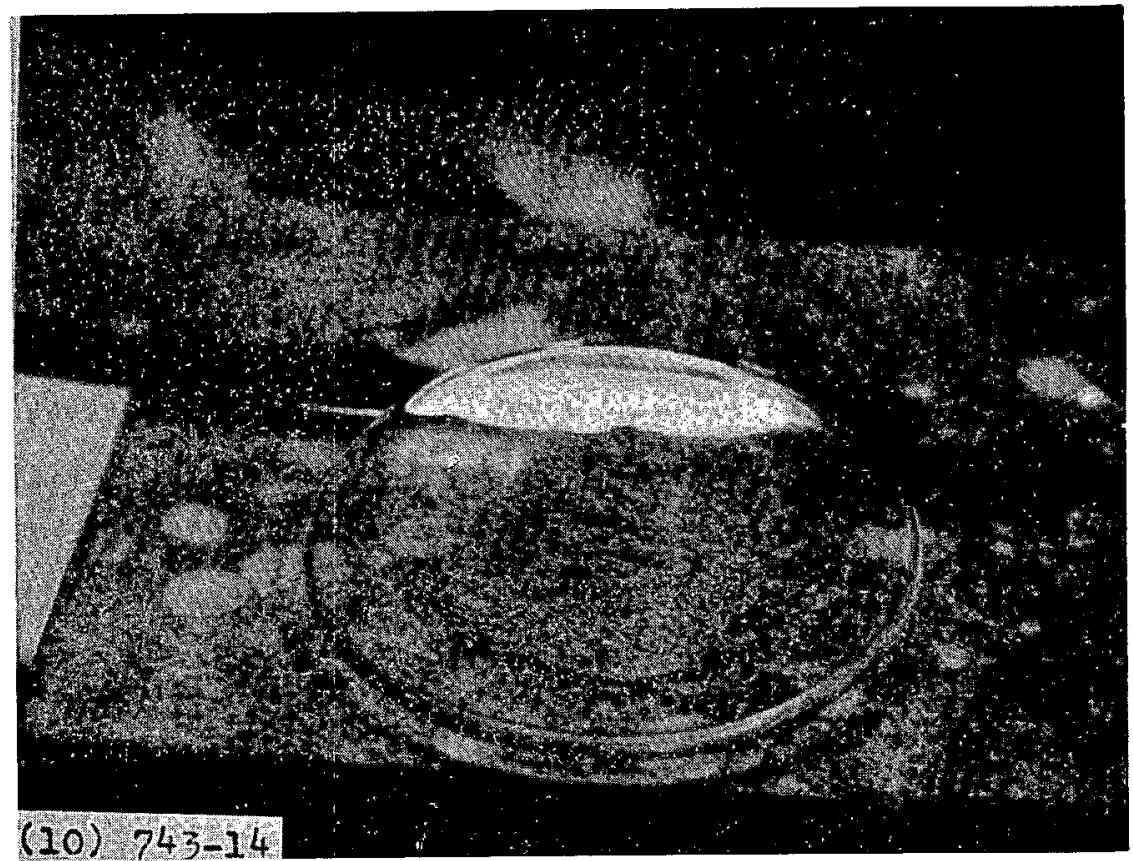

LMEC - P381 83

Figure B10. X-ray Diffraction Standard Preparation (743-14)

LMEC-77-7 


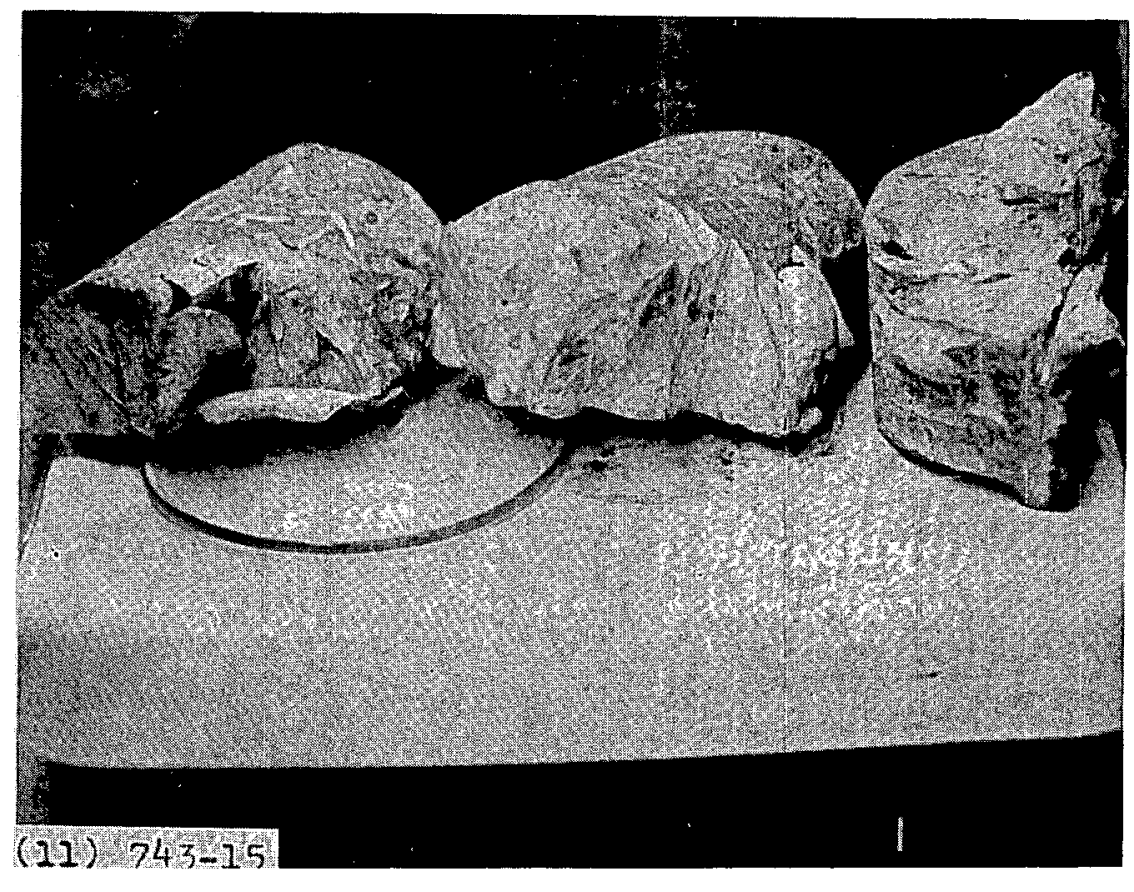

LMEC-P381 84

Figure Bll. Sections of SWRP, Showing Where Amalgamation Samples Were Removed (743-15)

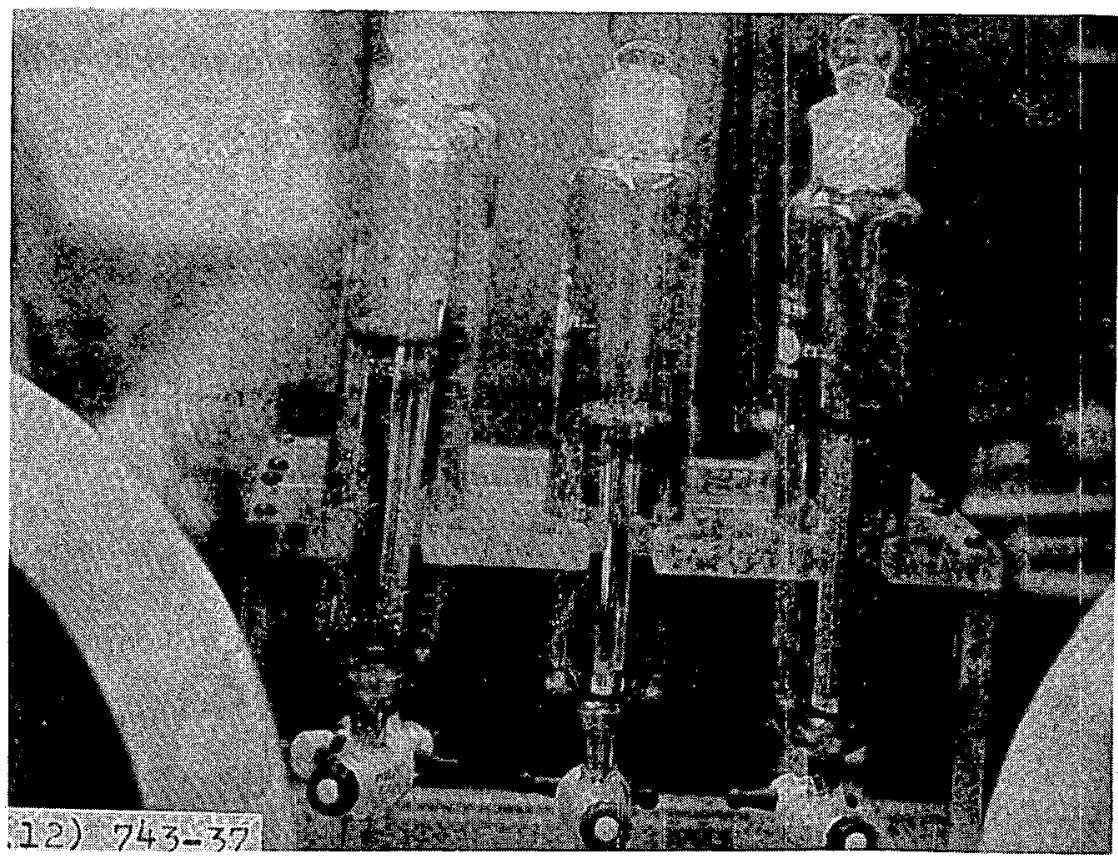

LMEC- P38185

Figure B12. Amalgamation Analysis, Showing Oxide Residue Floating on Mercury (743-37) 


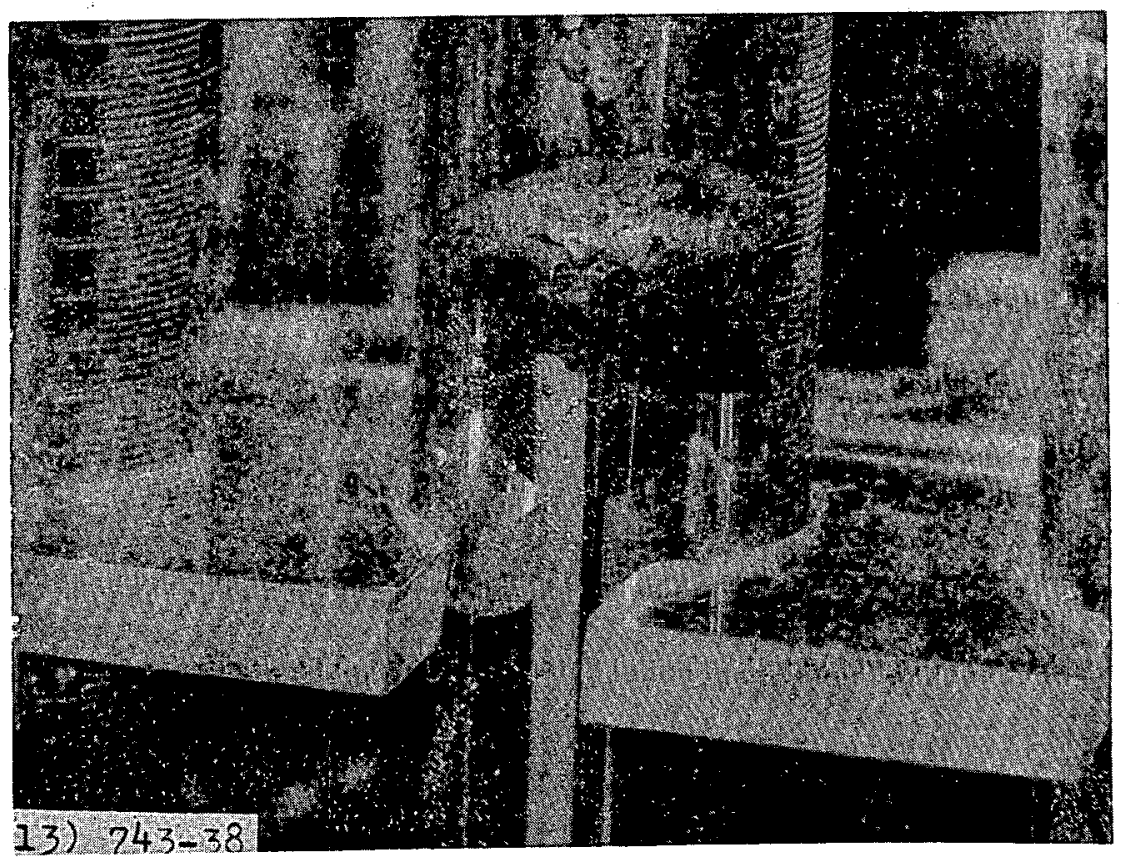

LMEC- P38186

Figure B13. Close-Up View of Oxide Residue on Mercury (743-38)

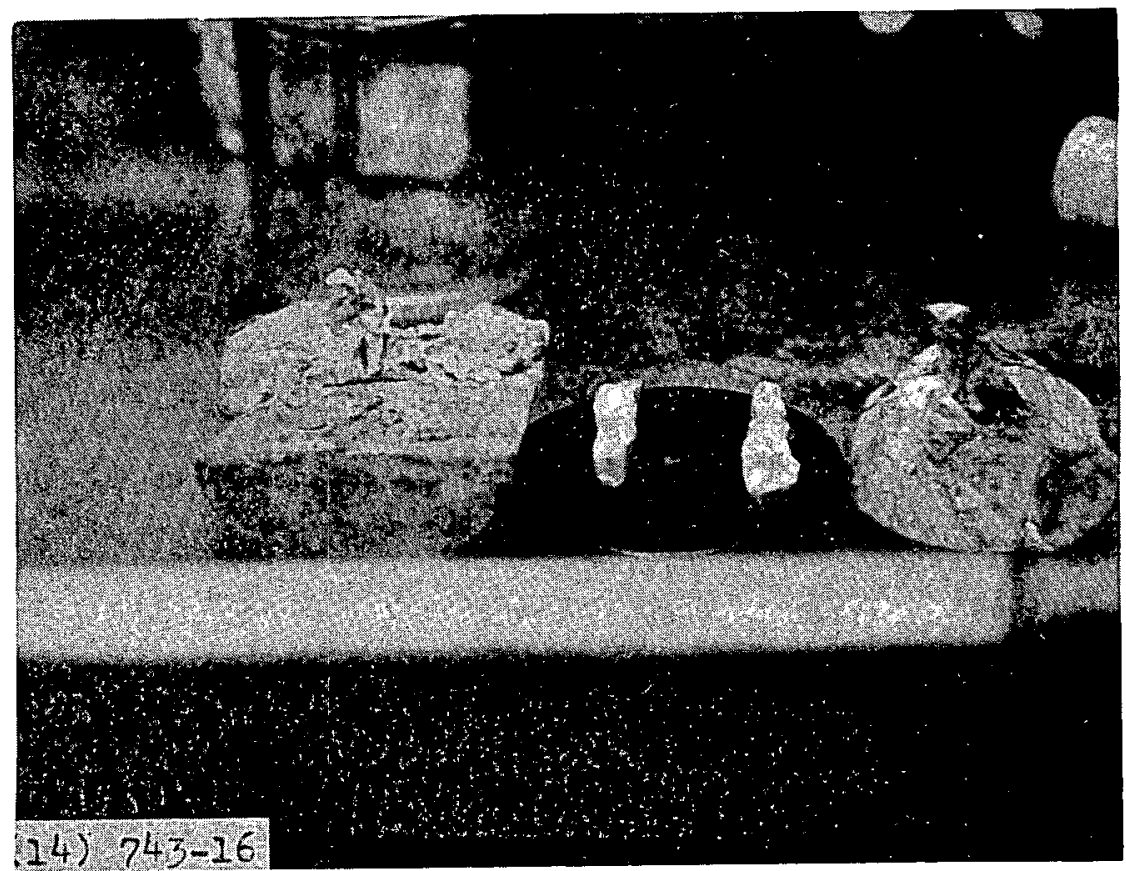

LMEC-P38187

Figure 14. Samples (center) Taken From SWRP Sections for Hydrogen Analysis (743-16)

LMEC-77-7 


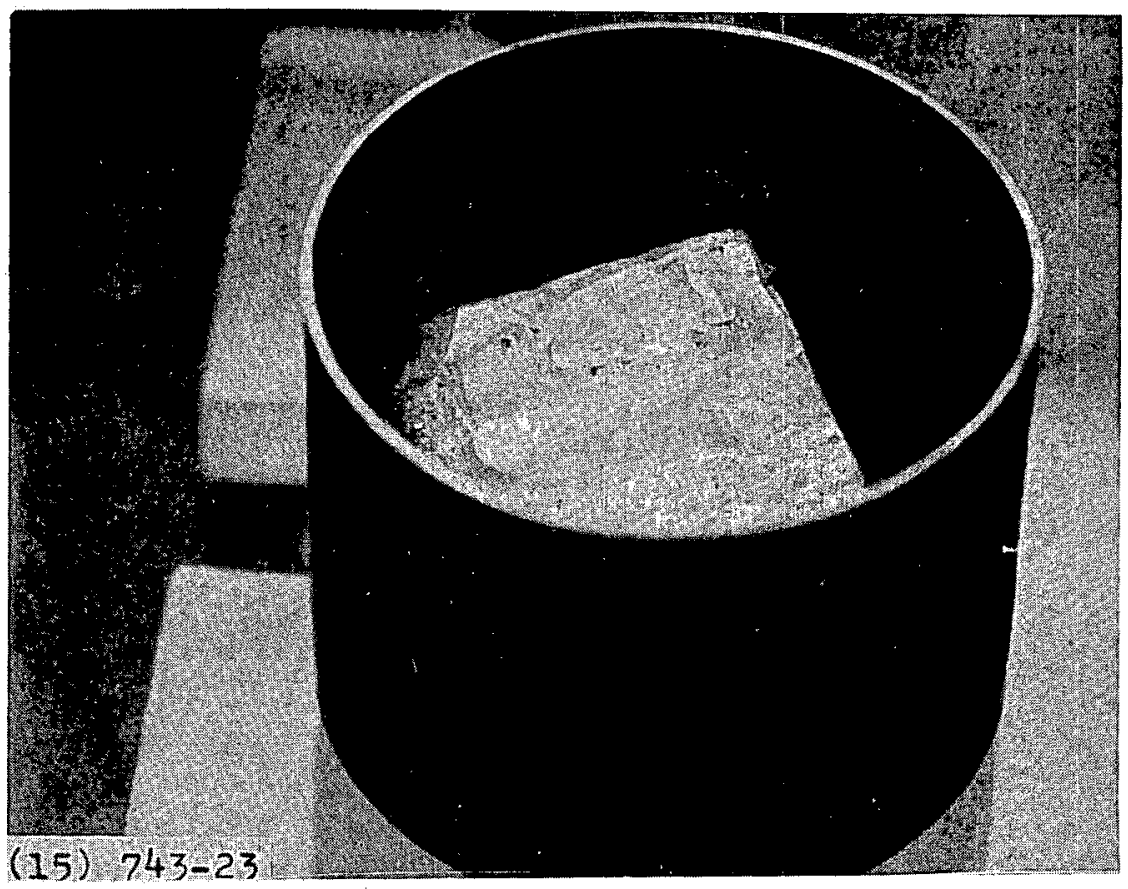

LMEC-P38188

Figure B15. SWRP Sample From Section No. 1 in Tantalum Crucible Before Distillation (743-23)

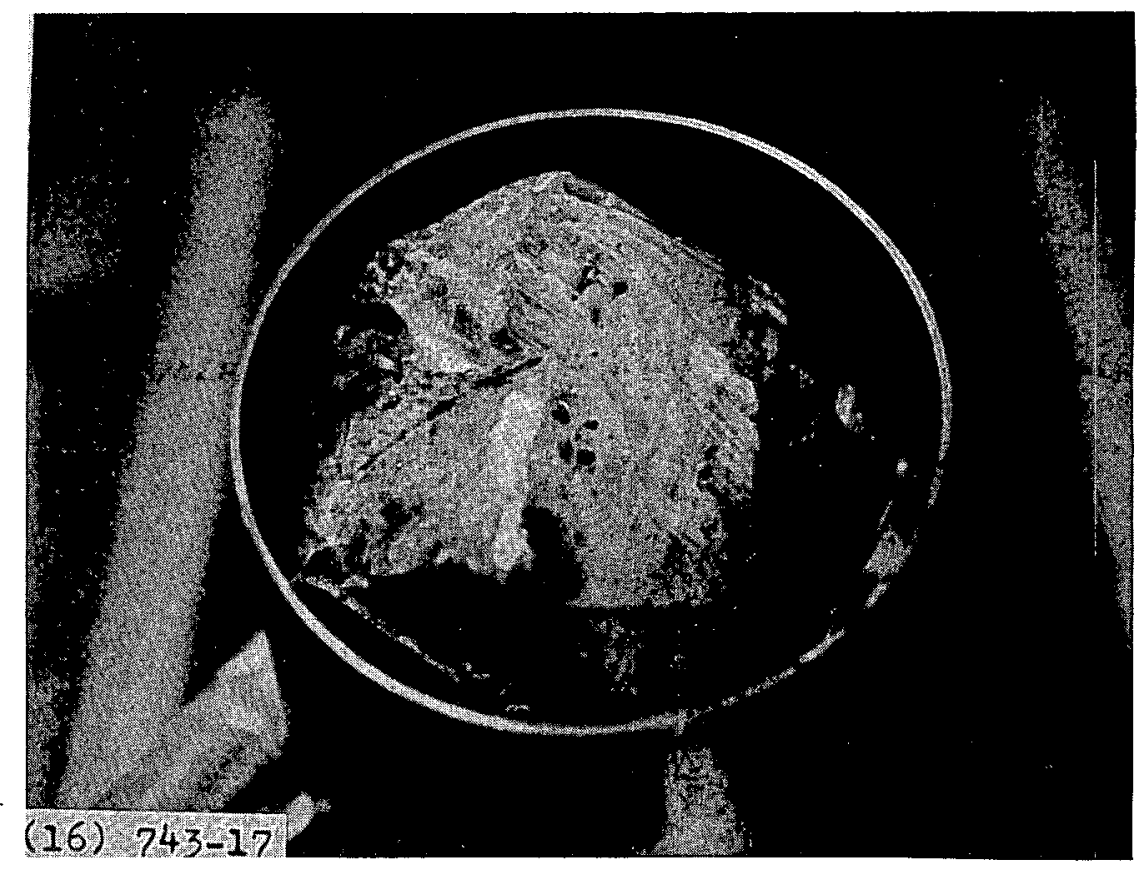

LMEC-P38189.

Figure B16. SWRP Sample From Section No. 4 in Tantalum Crucible Before Distillation (743-17) 


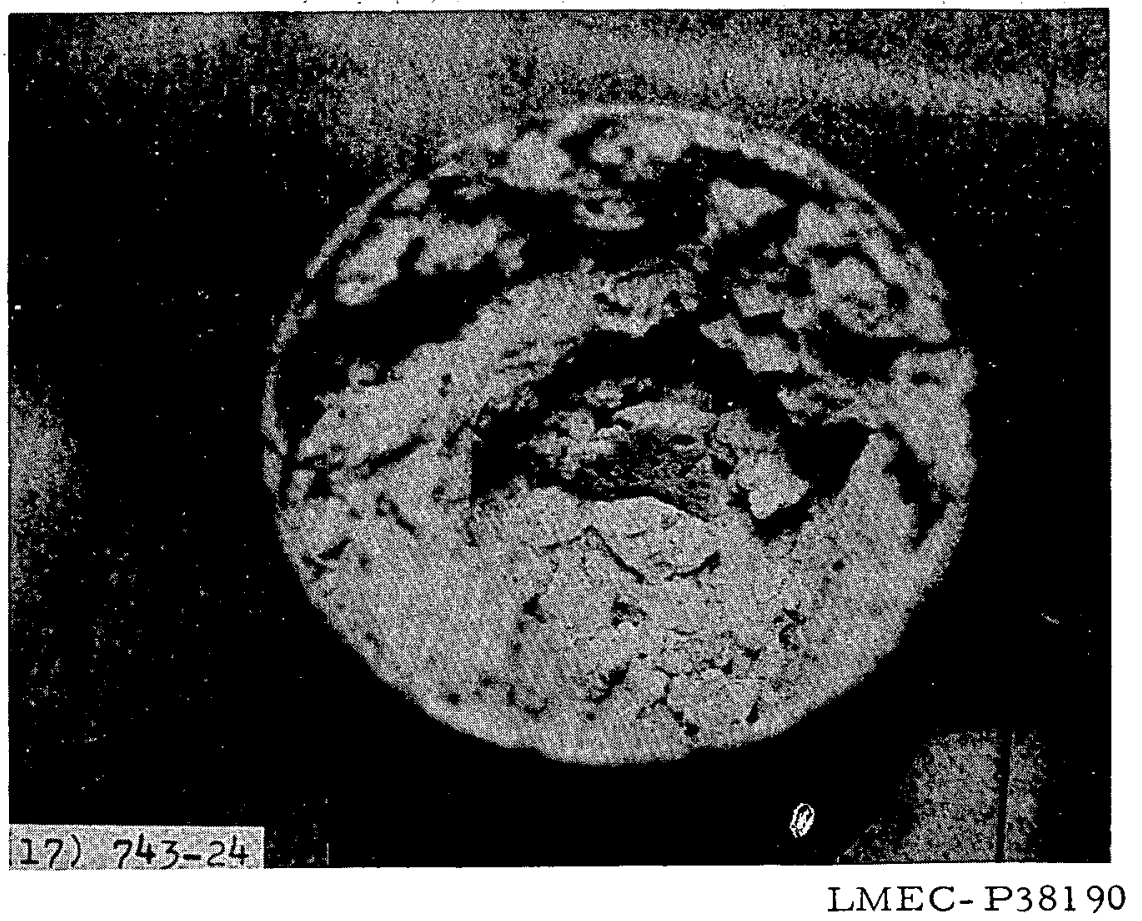

Figure B17. Distillation Residue From Section No. 1 (743-24)

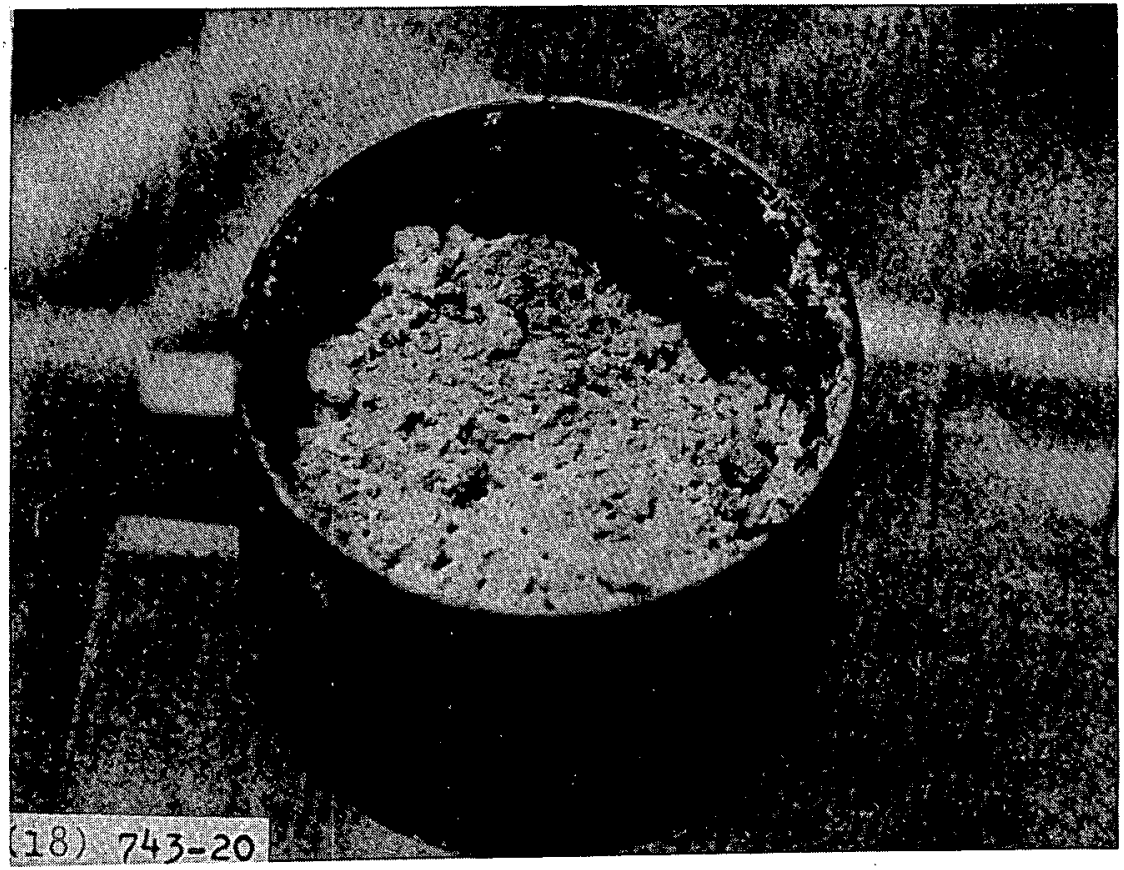

LMEC- P.38191

Figure B18. Distillation Residue From Section No. 4 (743-20) 


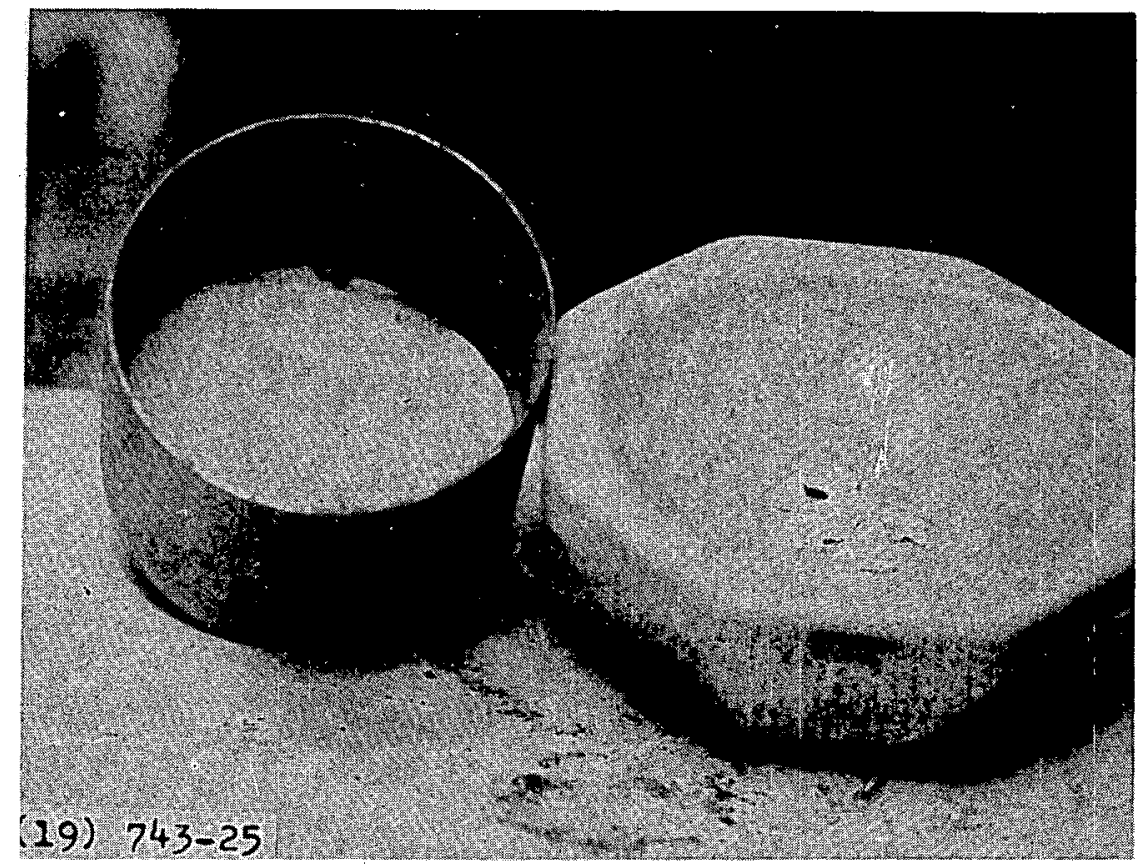

LMEC-P38192

Figure B19. Distillation Residue From SWRP Section No. 1: Separated Chunks in Mortar, Residue After Grinding in Crucible'(743-25)

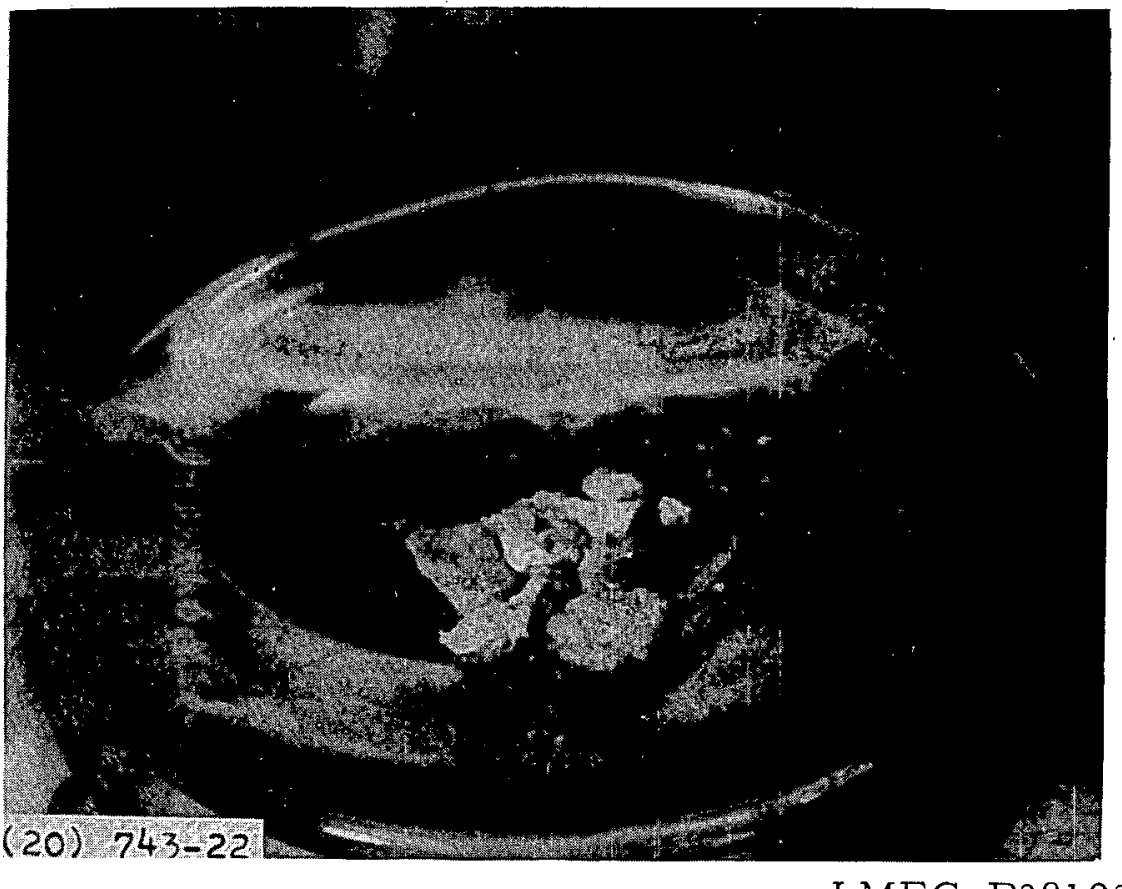

LMEC-P38193

Figure B20. Chunks Removed From SWRP Section No. 4 Distillation Residue (743-22)

LMEC-77-7 


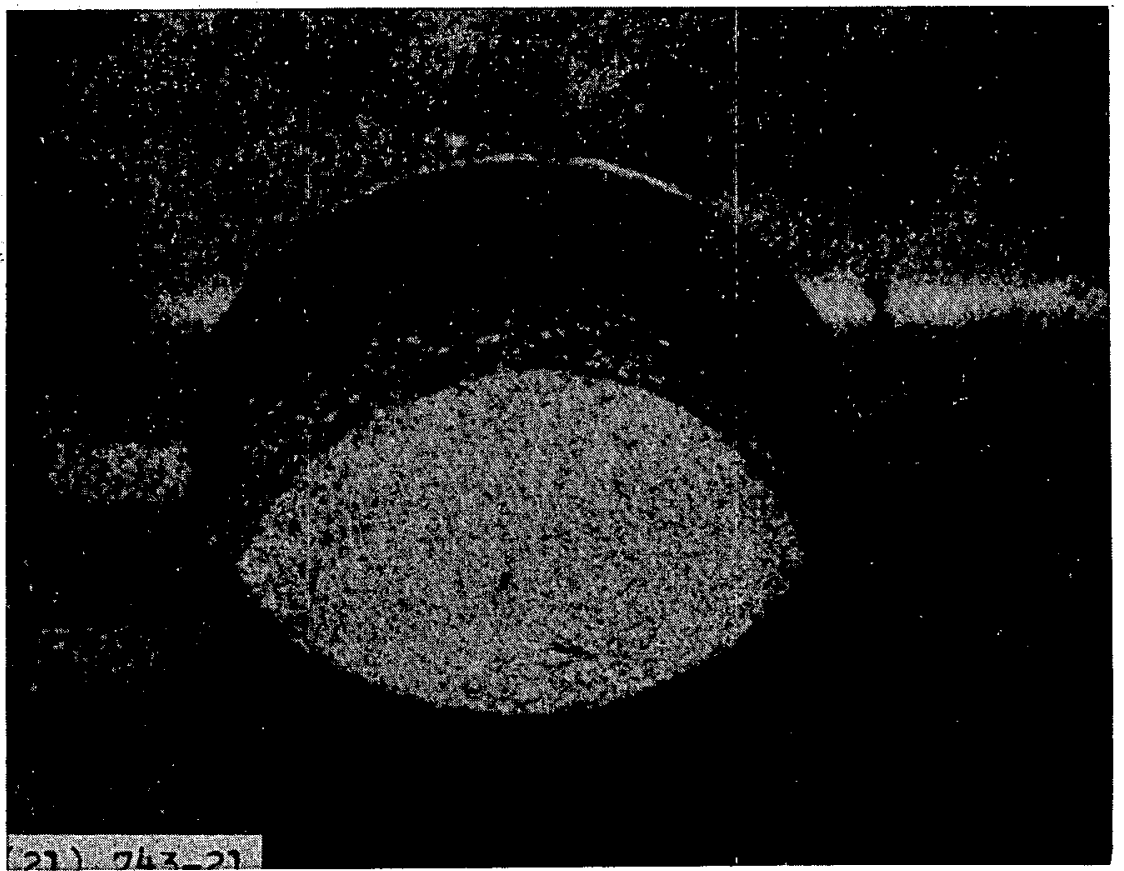

LMEC-P38194

Figure B21. SWRP Section No. 4 Distillation Residue After Grinding to Powder (743-21)

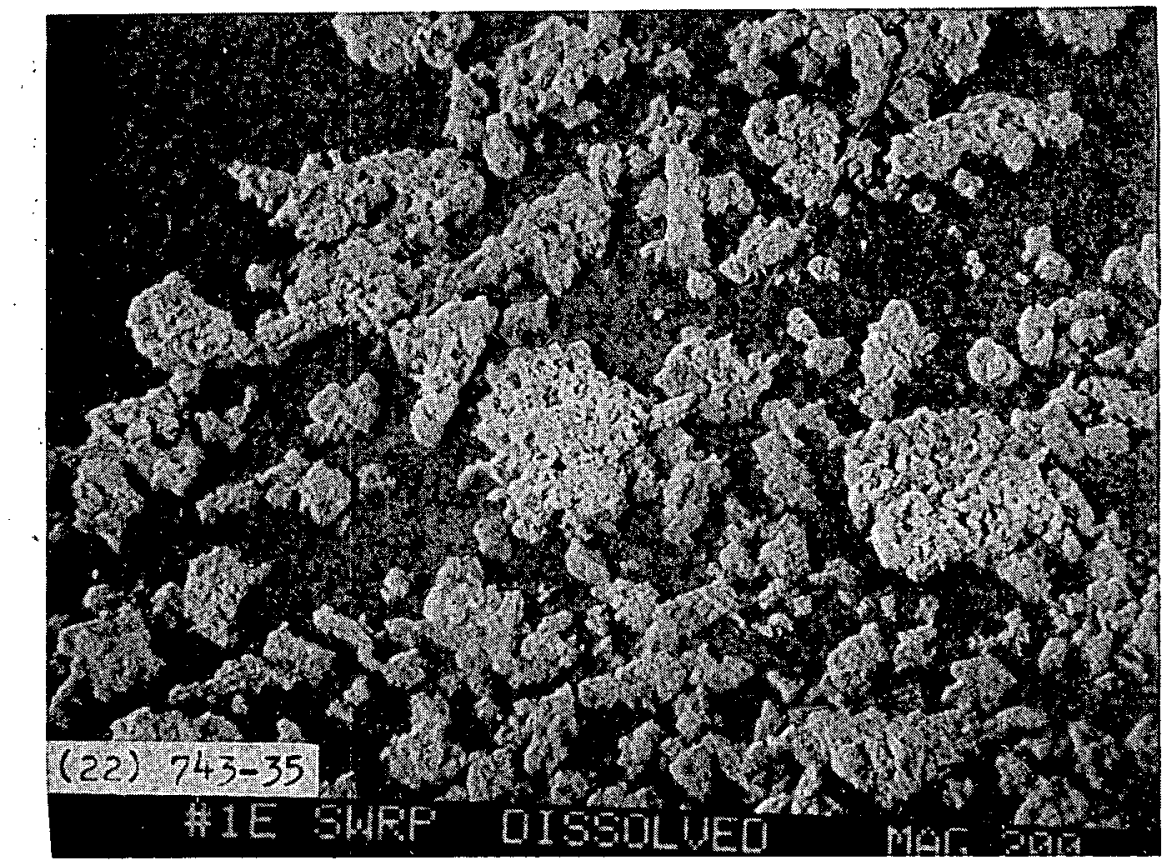

LMEC- P38195

Figure B22. Scanning Electron Micrograph of Magnetic Particles Recovered From SWRP Solution in Ethanol, 200X (743-35)

\section{LMEC-77-7}




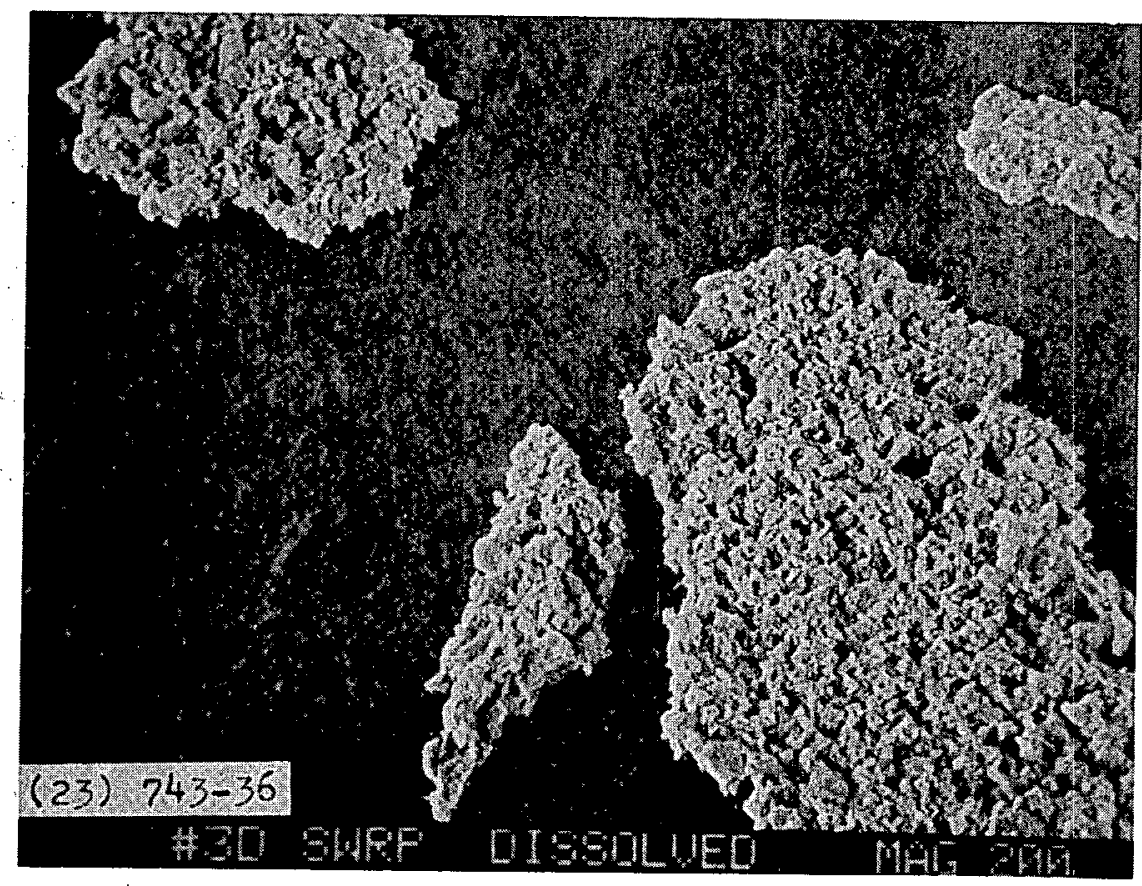

LMEC-P38196

Figure B23. Scanning Electron Micrograph of Magnetic Particles Recovered From SWRP Solution in Dowanol PM, 200X (743-36)

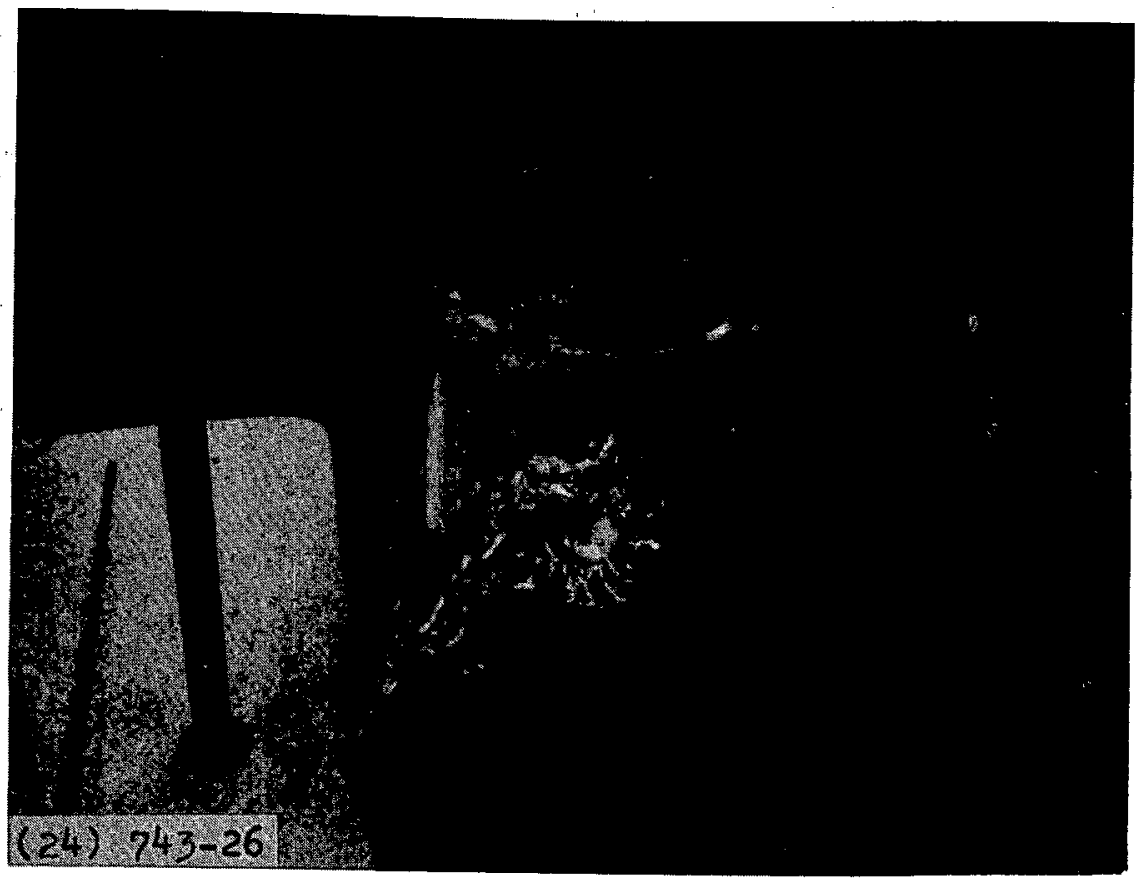

LMEC- P38197

Figure B24. SWRP Sample $(15.3 \mathrm{~g})$ in Glove Box at $550^{\circ} \mathrm{F}(743-26)$

LMEC- 77-7 


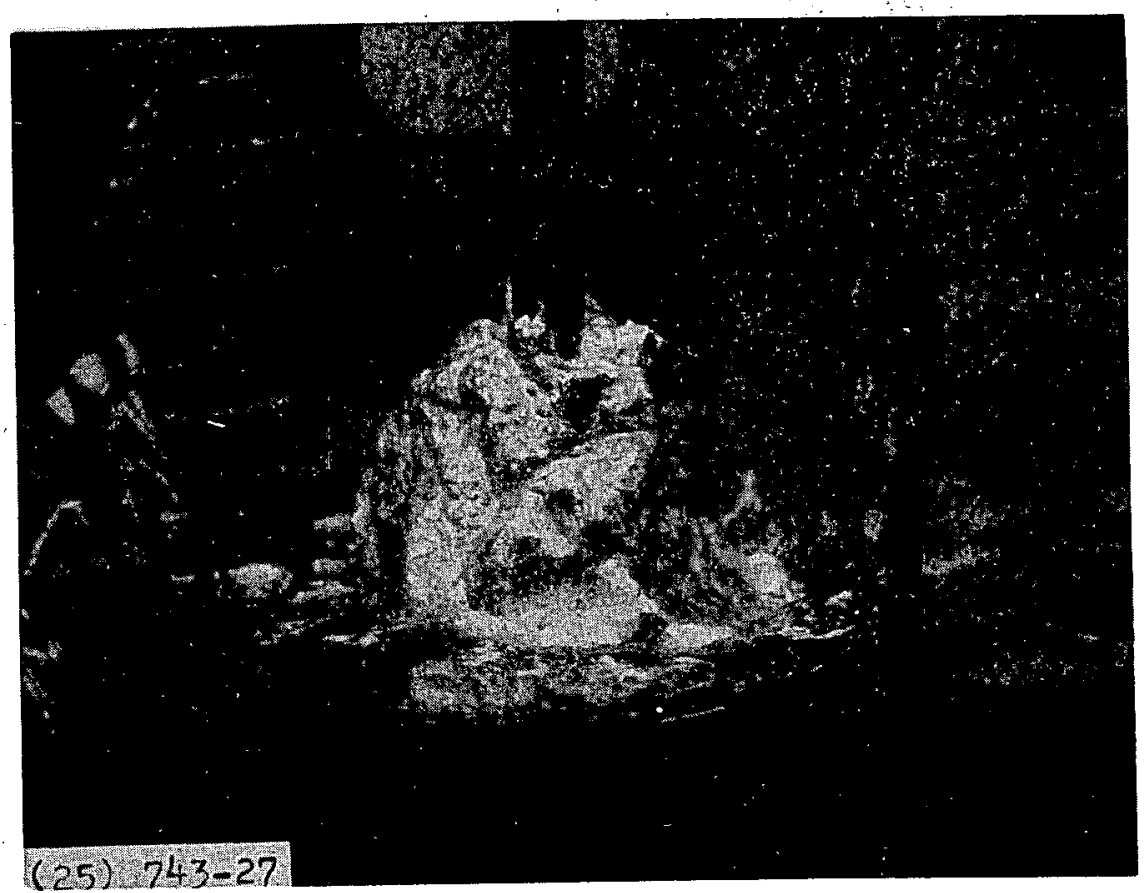

LMEC-P38198

Figure B25. Close-Up View of SWRP Sample at $500^{\circ} \mathrm{F}(743-27)$

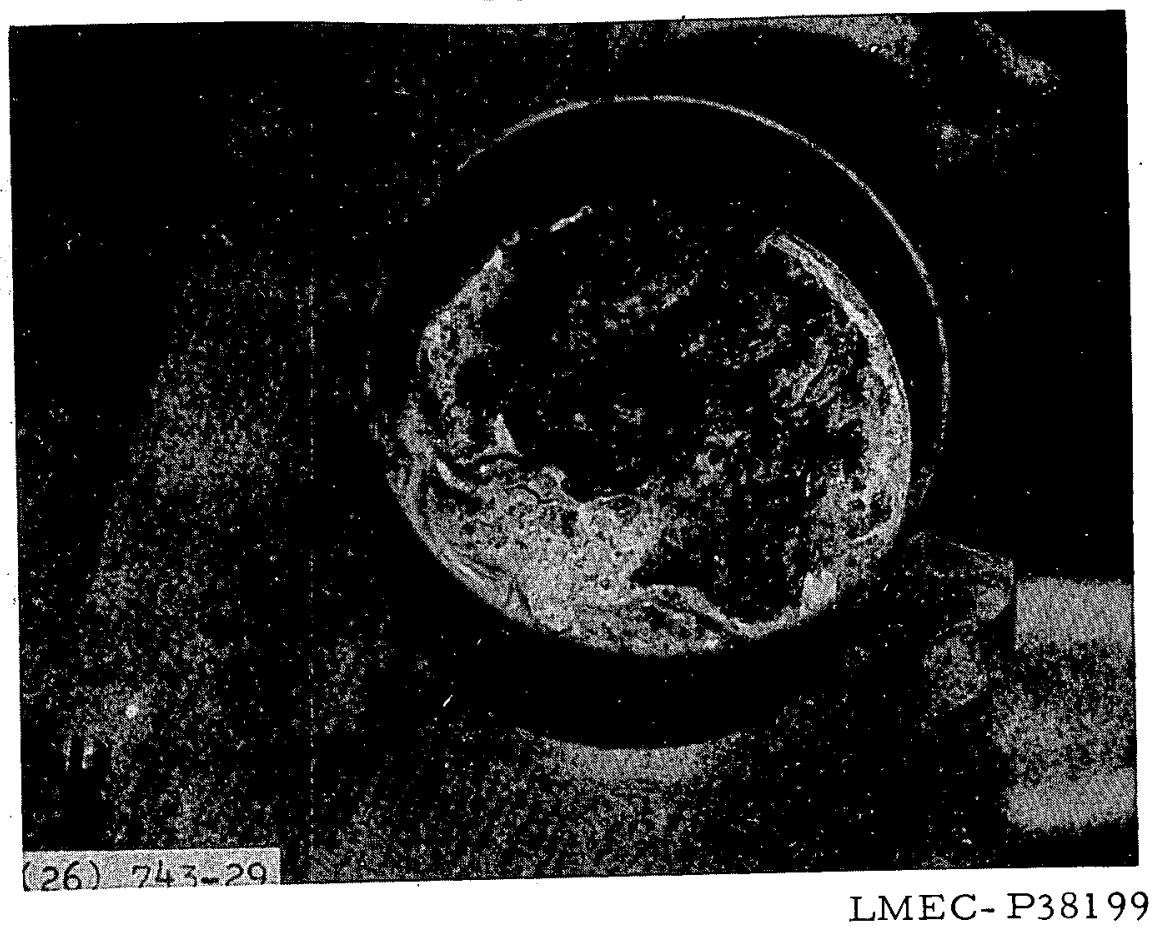

Figure B26. SWRP Sample (28.4 g) in Tantalum Cup After Heating to $800^{\circ} \mathrm{F}(743-29)$

LMEC-77-7 